\title{
Three-dimensional velocity structure of the northern Hikurangi margin, Raukumara, New Zealand: Implications for the growth of continental crust by subduction erosion and tectonic underplating
}

\author{
Daniel Bassett \\ School of Geography, Environment and Earth Sciences, Victoria University of Wellington, PO Box 600, Wellington, \\ Nerw Zealand (dangbassett@gmail.com)
}

\section{Rupert Sutherland and Stuart Henrys}

GNS Science, PO Box 30-368, Lower Hutt, New Zealand

\section{Tim Stern}

School of Geography, Environment and Earth Sciences, Victoria University of Wellington, PO Box 600, Wellington, New Zealand

\section{Martin Scherwath}

Leibniz Institute of Marine Sciences at University of Kiel (IFM-GEOMAR), Wischhofstrasse 1-3, D-24148 Kiel, Germany

Now at School of Earth and Ocean Sciences, University of Victoria, PO Box 3065, STN CSC, Victoria, British Columbia V8W 3V6, Canada

\section{Adrian Benson}

School of Geography, Environment and Earth Sciences, Victoria University of Wellington, PO Box 600, Wellington, Nerw Zealand

\section{Suzannah Toulmin}

Institute of Petroleum Engineering, Heriot-Watt University, Edinburgh EH14 4AS, UK

\section{Mark Henderson}

School of Geography, Environment and Earth Sciences, Victoria University of Wellington, PO Box 600, Wellington, New Zealand

[1] Traveltimes between shots from nine marine seismic reflection lines and nine onshore recorders were used to construct a 3-D $P$ wave velocity model of the northern Hikurangi subduction margin, New Zealand. From north to south between Raukumara Basin and Raukumara Peninsula, the Moho of the overriding plate increases in depth from 17 to $\sim 35 \mathrm{~km}$. Low seismic $P$ wave velocities of $3.5-5.0 \mathrm{~km} / \mathrm{s}$ are localized within a $\sim 10 \mathrm{~km}$ thick prism in the lower crust of the overriding plate immediately updip of the intersection between the subduction thrust and Moho and beneath the topographic crest of East Cape Ridge and the Raukumara Range. Southward, this region of low seismic velocities and surface uplift increases in distance from the trench as the thickness of the crust in the overriding plate increases. We interpret this low-velocity volume to be underplated sedimentary rocks and crustal materials that were tectonically eroded by subduction beneath the trench slope. The buoyancy and low strength of these subducted materials are proposed to assist the escape from a subduction channel near the base of the crust and drive local rock uplift. In the 
middle crust, our observations of very low velocity suggest high fluid-filled porosities of $12 \%-18 \%$, and the implied buoyancy anomaly may enhance underplating. At greater depths the process is driven by the contrast between upper crustal quartz-feldspar mineralogy and the denser diabase or olivine-rich lithologies of the lower crust and mantle. We estimate a rate of lower crustal underplating at the northern Hikurangi margin of $20 \pm 7 \mathrm{~km}^{3} \mathrm{Ma}^{-1} \mathrm{~km}^{-1}$ since $22 \mathrm{Ma}$. We suggest that underplating provides an efficient means of accreting subducted sediment and tectonically eroded material to the lower crust and that the flux of forearc crustal rocks into the mantle at subduction zones may be systematically overestimated.

Components: 12,100 words, 14 figures.

Keywords: seismic refraction; subduction; accretion; underplating; crustal growth; Hikurangi.

Index Terms: 8170 Tectonophysics: Subduction zone processes (1031, 3060, 3613, 8413); 3025 Marine Geology and Geophysics: Marine seismics (0935, 7294); 8015 Structural Geology: Local crustal structure.

Received 18 March 2010; Revised 21 July 2010; Accepted 29 July 2010; Published 21 October 2010.

Bassett, D., R. Sutherland, S. Henrys, T. Stern, M. Scherwath, A. Benson, S. Toulmin, and M. Henderson (2010), Threedimensional velocity structure of the northern Hikurangi margin, Raukumara, New Zealand: Implications for the growth of continental crust by subduction erosion and tectonic underplating, Geochem. Geophys. Geosyst., 11, Q10013, doi:10.1029/2010GC003137.

\section{Introduction}

[2] Subduction zones are the dominant physical and chemical systems of the Earth's interior (see review paper by Stern [2002]), and are the most obvious locations where continental material could be recycled back into the mantle. Documenting the fluxes of inputs and outputs at subduction margins provides insight into the growth and recycling of continental crust, and is central to our understanding of how Earth has chemically differentiated over long periods of geological time [Clift and Vannucchi, 2004; Hawkesworth and Kemp, 2006]. We present new observations and analyses that challenge assumptions that underpin previous estimates of crustal fluxes at subduction margins, and provide new insights into the tectonic underplating mechanism and the nature of underplated material.

[3] From observations of bathymetry, structure and morphology of the trench-slope and fore-arc basins at over 30 subduction zones of Phanerozoic activity, global fluxes of subduction zone material transfer have been estimated [e.g., von Huene and Scholl, 1991; Clift and Vannucchi, 2004]. The assumption of vertical rock trajectories within the fore-arc wedge has allowed rates of trench slope subsidence, interpreted as a direct manifestation of subduction erosion, to be coupled with estimated rates of sediment supply/accretion to estimate the flux of fore-arc material to the mantle at subduction margins to be $90 \mathrm{~km}^{3} \mathrm{Ma}^{-1} \mathrm{~km}^{-1}$ [Clift and Vannucchi, 2004]. Integration of onshore data and evidence suggesting efficient (up to 85\%) underplating of subducted and tectonically eroded strata along the Andean margin [Clift and Hartley, 2007] has reduced the estimated global flux of sediment to the mantle to $\sim 74 \mathrm{~km}^{3} \mathrm{Ma}^{-1} \mathrm{~km}^{-1}$ [Clift et al., 2009] Previous suggestions of trench retreat [Ballance et al., 1999] and evidence of mass wasting [Collot and Davy, 1998] at the Hikurangi-Kermadec subduction zone resulted in its classification as an erosional margin in a state of subduction mass balance deficit, and hence it contributes to global flux estimates [von Huene and Scholl, 1991; Clift and Vannucchi, 2004].

[4] The northern Hikurangi subduction margin is characterized by margin-parallel transitions in crustal structure within both the fore arc and subducting plates (Figure 1). In the overriding (Australian fore-arc) plate, the anomalously high topography of the Raukumara Ranges [Walcott, 1987] transforms northeast along strike into the deep ( $>10 \mathrm{~km}$ sediment thickness, $>2 \mathrm{~km}$ water depth) Raukumara Basin (Figure 2) [Sutherland et al., 2009]. Northeast of this transition, the Rapuhia Scarp on the subducting (Pacific) plate marks the northern boundary between the Hikurangi Plateau large igneous province (crustal thickness 10-23 km) and Mesozoic oceanic crust [Davy and Wood, 1994; Davy et al., 2008]. The anomalous topography [Walcott, 1987], $\mathrm{V}_{\mathrm{p}}$ structure [Reyners et al., 1999], Quaternary [Litchfield et al., 2007] and Neogene [Litchfield and Berryman, 2006] uplift rates, Pliocene strain estimates [Nicol et al., 2007] 


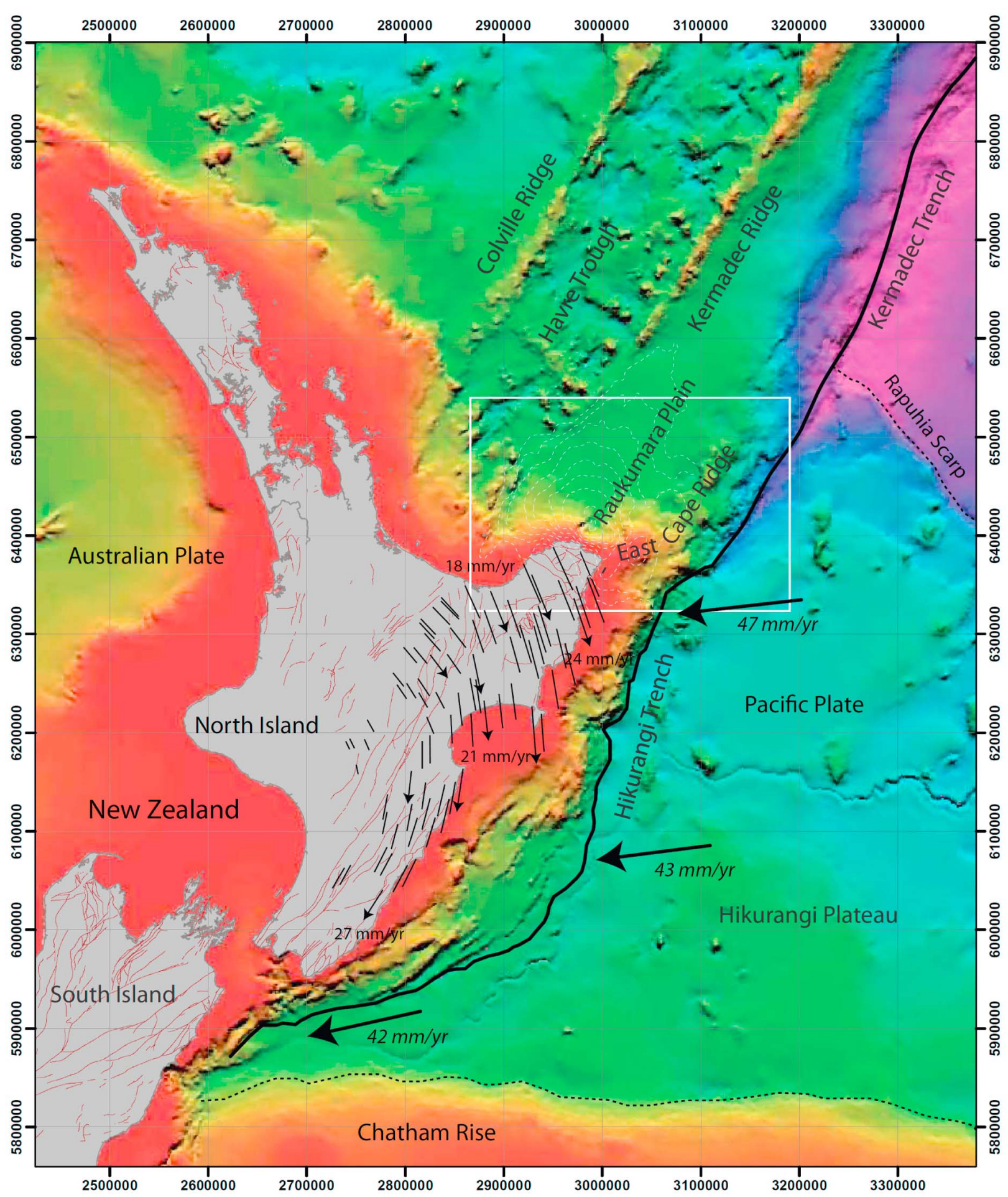

Figure 1. Bathymetric map displaying the regional tectonic setting of the North Island, New Zealand (National Institute of Water and Atmospheric sciences (NIWA)). Subduction of the Hikurangi Plateau (onboard the Pacific plate) beneath the North Island occurs at rates increasing northward along strike [Beavan et al., 2002]. Long-term forearc rotation relative to the Australian Plate (black vectors onshore, rates displayed) results in near-orthogonal subduction beneath the East Cape [Wallace et al., 2004]. White box displays the regional focus of this study and the area displayed in Figure 2. Dashed contour (intervals $20 \mathrm{mgal}$, innermost contour $-150 \mathrm{mgal}$ ) illustrates the geometry of the Raukumara free-air gravity anomaly. The Rapuhia Scarp marks the northern boundary of the Hikurangi Plateau and a transition to Mesozoic oceanic crust [Davy and Collot, 2000]. Onshore active faults are plotted in red (GNS Science, active fault database). 


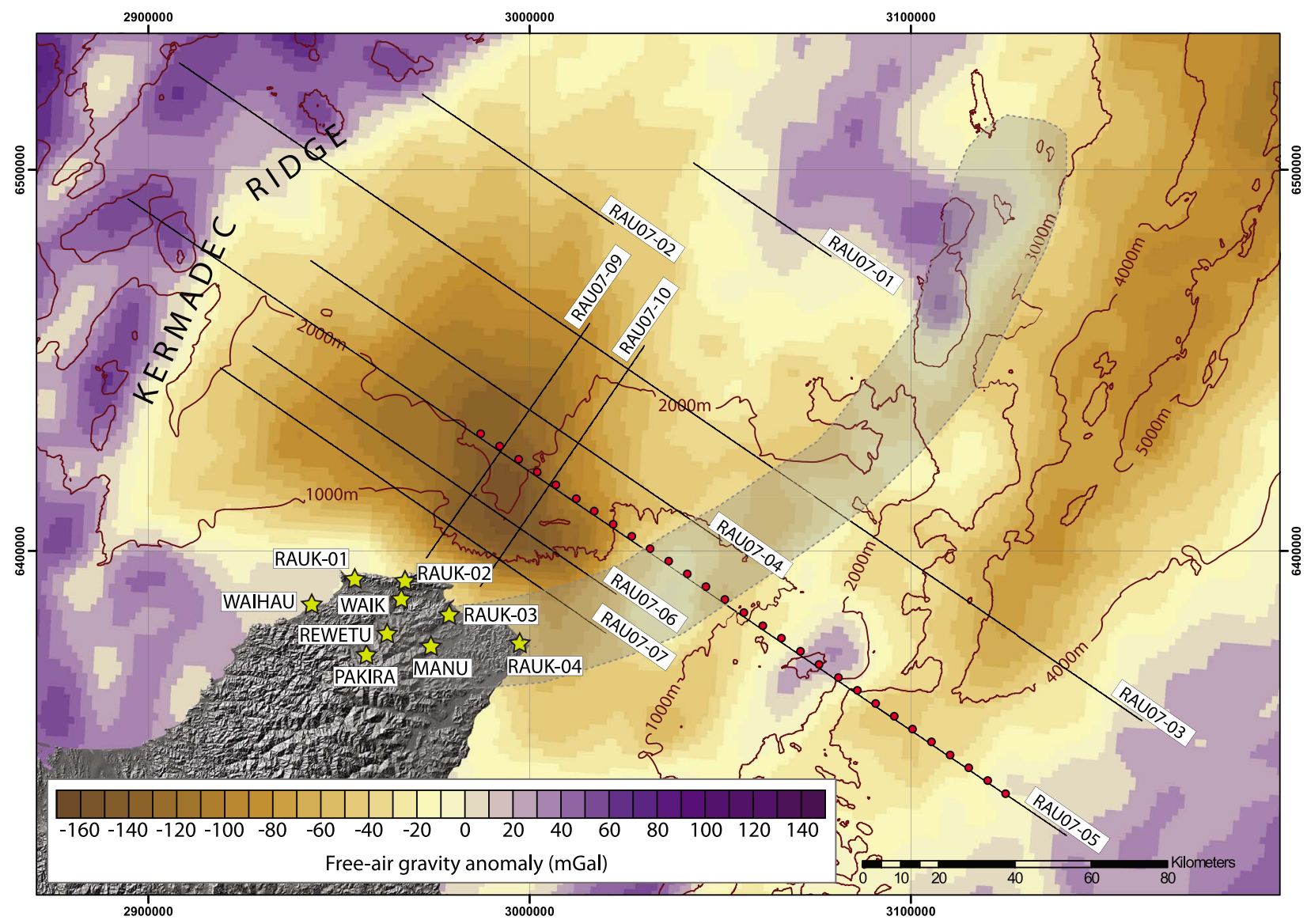

Figure 2. Free-air gravity map illustrating the acquisition geometries of onshore-offshore wide-angle seismic reflection and refraction data. Shots originating from RAU07 seismic reflection profiles (black). were recorded onshore by nine three-component short-period seismometers (yellow stars). Bathymetric contours at $1000 \mathrm{~m}$ intervals are plotted in red with a digital elevation model (DEM) used to display the Raukumara Peninsula. Red dots denote the locations of Ocean Bottom Seismometers/Hydrophones used in the earlier study of Scherwath et al. [2010]. The Kermadec Ridge bounds the western flank of Raukumara Basin. The East Cape Ridge, which bounds the eastern flank, is displayed in gray.

and deformation of Pleistocene marine terraces [Wilson et al., 2007], which characterize the northern Raukumara Peninsula, have been interpreted as manifestations of lower crustal underplating.

[5] From the interpretation of high-fold seismic reflection data and preliminary interpretations of refraction data across Raukumara Basin, Sutherland et al. [2009] developed a cyclical fore-arc kinematic model to explain the geometry of lower crustal underplating. In a more detailed study of active source seismic refraction data along an offshore 2-D dip transect across Raukumara Basin, Scherwath et al. [2010] identified a low- $V_{p}$ volume beneath East Cape Ridge that was inferred to represent underplated material.

[6] In this study, we analyze onshore-offshore wide-angle seismic reflection and refraction data to constrain the first 3-D forward model of $V_{p}$ structure across the transition between Raukumara Plain and Raukumara Peninsula at the northern Hikurangi margin. This model places constraints on key parameters such as Moho geometry, subducting slab geometry and fore-arc basement thickness, which may modulate the location of lower crustal underplating. Although the available raypaths provide barely adequate coverage to constrain some parts of our 3-D model, we have better along-strike ray coverage over appropriate offsets $(20-100 \mathrm{~km})$ than most other studies of subduction zones, and hence we place strong constraints on the absolute velocity of the shallow $(<20 \mathrm{~km})$ fore-arc crust, including material that we infer to be underplated. We integrate our model with published $V_{p}$ volumes derived using earthquake tomography farther south [Reyners et al., 1999, 2006] and hence analyze the 
tectonic underplating process and crustal budget along a $350 \mathrm{~km}$ length of the Hikurangi margin.

\section{Present Tectonic Setting}

[7] The rate of near-orthogonal subduction of the Pacific plate beneath the Raukumara Peninsula is $\sim 60 \mathrm{~mm} / \mathrm{yr}$; and the relative motion is caused by a combination of oblique Australia-Pacific relative plate motion trending $50^{\circ}$ to the trend of the margin ( $\sim 7 \mathrm{~mm} / \mathrm{yr})$ [DeMets et al., 1994; Beavan et al., 2002] and back-arc extension within the Taupo Volcanic Zone and Havre Trough ( 13-16 mm/yr) [Wallace et al., 2004; Lamarche et al., 2006]. Plate convergence at the Hikurangi margin is principally accommodated on the subduction thrust $(>80 \%)$ with the remaining margin normal, and the majority of margin parallel displacement accommodated in the upper plate through a combination of reverse faulting, strike slip faulting and vertical axis clockwise rotations [Walcott, 1984; Lamb, 1988; Nicol et al., 2007, and references therein].

[8] The Hikurangi Plateau, currently subducting onboard the Pacific plate, has an estimated crustal thickness of 10-23 km [Davy et al., 2008], which in the region near the Raukumara Peninsula is suggested to be 10-15 km thick [Reyners et al., 1999; Henrys et al., 2006; Scherwath et al., 2010]. The subduction of this anomalously thick crust has been causally related to the subaerial exposure of the fore arc along the East Coast of the North Island [Davy and Wood, 1994; Davy et al., 2008].

[9] Onshore, tomography, controlled source seismic and receiver function analyses of naturally occurring earthquakes suggests a crustal thickness of 30-40 km beneath the east coast of the North Island [Stern and Davey, 1985; Reyners et al., 1999; Bannister et al., 2004; Reyners et al., 2006; Horspool et al., 2006; Henrys et al., 2006]. A region of comparatively low $\mathrm{V}_{\mathrm{p}}\left(5.5-6.5 \mathrm{~km} \mathrm{~s}^{-1}\right)$ and low $Q_{p}$ is found at depths of $10 \mathrm{~km}$ to $\sim 30 \mathrm{~km}$ beneath the northeastern Raukumara Ranges, and these physical properties have been interpreted to be caused by underplated sediment [Reyners et al., 1999; Eberhart-Phillips and Chadwick, 2002].

[10] Offshore near to the coast, there is a transition to the Raukumara Basin [Katz, 1974; Dickinson and Seely, 1979; Gillies, 1984; Gillies and Davey, 1986; Davey et al., 1997; Sutherland et al., 2009; Scherwath et al., 2010]. Sediment cover of the Raukumara Plain was revealed by low-fold seismic reflection and sonobuoy seismic refraction surveys conducted in the 1970s and 1980s [Katz, 1974;
Gillies, 1984]; but the full thickness of sedimentary fill $(>10 \mathrm{~km})$ was not appreciated until a high-fold seismic reflection profile spanning the fore arc, arc and back arc was acquired in 1990 [Davey et al., 1997]. Raukumara Basin is prospective for petroleum [Stagpoole et al., 2008] and hence it was imaged in its southern region by the 2005 O5CM [Maslen, 2005; Multiwave, 2005; Barker et al., 2009] and the 2007 RAU07 high-fold seismic reflection surveys [Sutherland et al., 2009]. In addition, a 2007 experiment using a large seismic source and an array of ocean bottom instruments created a refraction model across the subduction zone along one of the RAU07 reflection lines [Scherwath et al., 2010]. The Moho beneath Raukumara Basin is shown along this reflectionrefraction profile to be at $\sim 17 \mathrm{~km}$ depth and, excluding the sedimentary basin fill, the crustal basement beneath Raukumara Plain is $\sim 4-7 \mathrm{~km}$ thick and thus likely of oceanic origin [Gillies, 1984; Sutherland et al., 2009; Scherwath et al., 2010].

[11] At the northern Hikurangi margin, earthquake hypocenters are focused within the subducting slab with a sparser distribution throughout the overriding plate (Figures $6 \mathrm{a}$ and $6 \mathrm{~b}$ ). Focal mechanisms reveal the differing strain regimes between these regions and NNW-SSE extensional strain is implied within the upper plate [Reyners and McGinty, 1999]. Low-angle thrusting mechanisms are observed near to the plate interface, and deeper normal faulting events suggest downdip tensional strain within the crust of the subducting slab [Reyners and McGinty, 1999; Henrys et al., 2006]. The plate interface at $15-20 \mathrm{~km}$ depth is resolved as a $1-2 \mathrm{~km}$ thick zone with $\mathrm{V}_{\mathrm{p}}$ of $5.0-5.35 \mathrm{~km} \mathrm{~s}^{-1}$ and $\mathrm{V}_{\mathrm{p}} / \mathrm{V}_{\mathrm{s}}$ of 2 , which is interpreted as a subduction channel or underplated material containing fluids at near-lithostatic pressure [Reyners et al., 1999; Eberhart-Phillips and Reyners, 1999].

\section{Onshore-Offshore Data}

[12] The RAU07 multichannel seismic (MCS) reflection survey consisted of nine profiles totaling 1128 line kilometers, recorded in July 2007 onboard CGG Duke (Figure 2). The seismic source was a 86.61 (5280 cu in) air gun array, charged to a pressure of $18.8 \mathrm{MPa}$ (2000 psi) [Fugro Seismic Imaging, 2007]. In addition to high-incidence reflected arrivals recorded by a $7.3 \mathrm{~km}$ streamer, wide-angle reflected and refracted arrivals were recorded onshore by nine three-component shortperiod seismometers deployed around the northern 


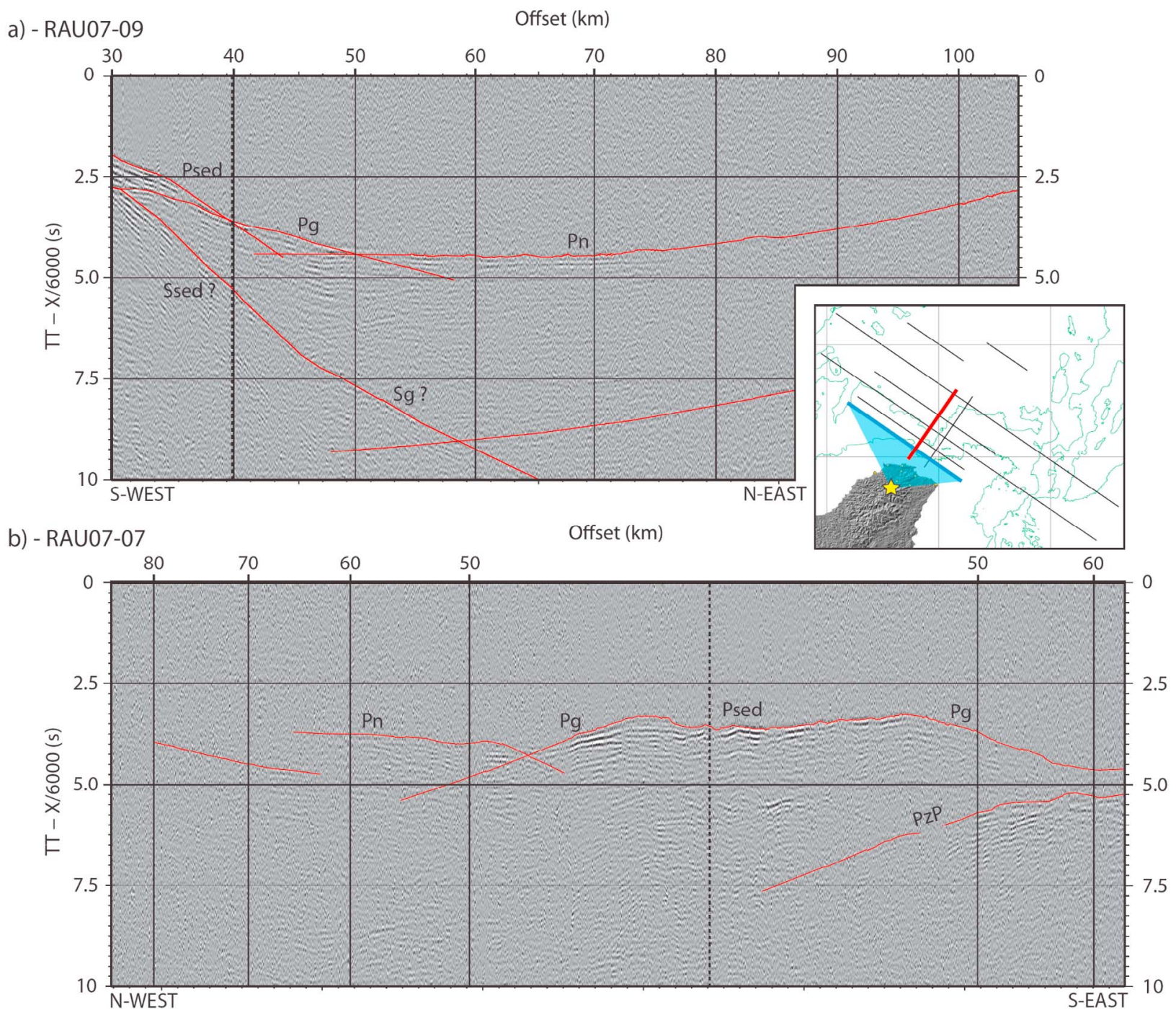

Figure 3. Interpreted receiver gathers for onshore-offshore data originating from shot points along (a) RAU07-09 (red, see inset) and (b) RAU07-07 (blue), as recorded at Pakira (yellow star in inset). Traces are plotted with equal spacing, and data are reduced to $6 \mathrm{~km} \mathrm{~s}$. Interpretations are displayed in red along with preliminary phase interpretations. Vertical black lines (labeled) provide offset markers, and the intersection of RAU07-09 and RAU07-07 is plotted as a dashed line. Note the approximately constant number of traces plotting within each offset range along RAU07-09 and the contrast with the trace offset distribution along RAU07-07. RAU07-09 is approximately in line with Pakira and does not experience the variations in ray azimuth-profile obliquity, which occur along RAU07-07 compromising apparent velocities and thus increasing the difficulty of determining phase identity along cross-line profiles. The blue region in the inset displays the area of crust sampled by rays originating from RAU07-07.

Raukumara Peninsula. Shot intervals were $37.5 \mathrm{~m}$ with the exception of RAU07-05 $(50 \mathrm{~m})$.

[13] Onshore-offshore data were organized as a suite of 81 receiver gathers, with reflected and refracted arrivals interpreted on the basis of geometry and traveltime (Figures $3 \mathrm{a}$ and $3 \mathrm{~b}$ ). Coherent arrivals were identified on 69 gathers and in total, we identify $\sim 275,000$ traveltime picks across 174 discrete phase segments. The degree of precision in arrival time ranges from $70 \mathrm{~ms}$ to $1 \mathrm{~s}$, depending on noise levels and relationships to overlapping arrivals, the vast majority of picks having a precision of $<200 \mathrm{~ms}$.

[14] Data from shots from the Raukumara Plain (Figures 1 and 2) display coherent high-amplitude arrivals. Four phases were identified: a reflection from the plate interface (PzP) (Figure 3b); and a series of refracted rays turning within sedimentary basin fill (Psed), fore-arc basement $(\mathrm{Pg})$ and the mantle wedge (Pn) (Figures $3 \mathrm{a}$ and $3 \mathrm{~b}$ ). Where 

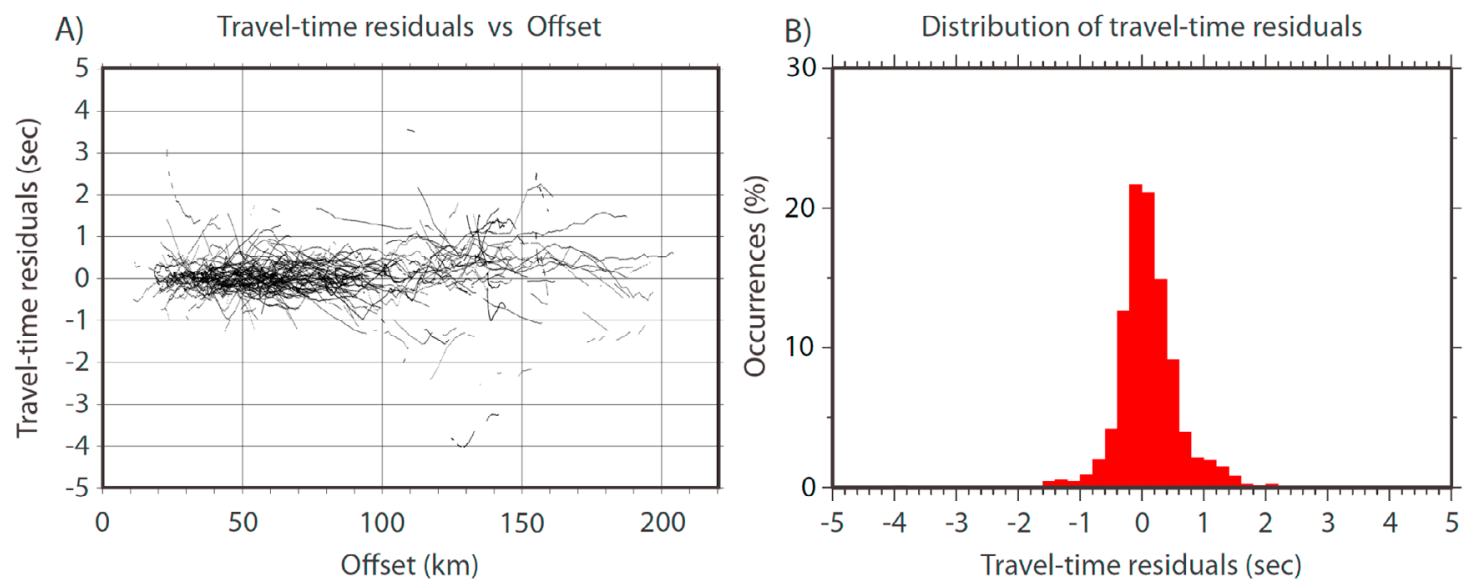

Figure 4. (a) Traveltime residuals ( $\mathrm{T}$ obs $-\mathrm{T}$ calc) versus offset calculated for the final velocity forward model. (b) Distribution of traveltime residuals.

RAU07 profiles cross the East Cape Ridge region (Figure 2), coherent arrivals that are continuous with those from the central and eastern Raukumara Plain display slower apparent velocities and considerably lower amplitudes (Figure 3b), suggesting slower crustal velocities and higher attenuation. The highest-amplitude phases sampling the crust beneath East Cape Ridge are interpreted as reflected and refracted arrivals from the subducting slab. A single arrival is observed from shots east of East Cape Ridge at offsets from 80 to $210 \mathrm{~km}$. We interpret this phase as a refraction turning within the mantle of the subducting lithosphere.

\section{Three-Dimensional Velocity Model}

\subsection{Method}

[15] The raypaths used in our study pass beneath a $\sim 32,000 \mathrm{~km}^{2}$ area of the northern Hikurangi margin. We constructed a relatively simple layered $P$ wave velocity forward model of the volume beneath, because the geometries of the rays are not sufficiently dense for a reliable tomographic inversion, but can be modeled if certain assumptions are made (below). Most of the RAU07 survey was composed of dip-parallel profiles, so most of our recorded raypaths fan out to the northeast and are roughly parallel to the strike of the subduction zone. Unlike the majority of seismic refraction surveys, which are acquired as 2-D dip profiles [e.g., Dowling, 1968; Spence et al., 1985; Tréhu et al., 1995; Lafond and Levander, 1995; Stern et al., 2001; Scherwath et al., 2003], the large number of strike-parallel raypaths in our study constrain well the absolute velocities of layers, because the geometry of layer interfaces along strike are generally less complex than downdip.

[16] Our model was constructed as a series of laterally extensive layers, each encompassing the full model area. The geometries of layer boundaries were adjusted along 2-D lines and then 3-D grids of layer boundaries were constructed by minimum curvature interpolation between profiles and, from these grids, the velocity volume was interpolated in a layer cake fashion using specified velocities at the upper and lower surfaces of each model layer. Synthetic traveltimes were calculated using the multistage fast marching method (FMM) [Sethian, 1996; Sethian and Popovici, 1999; Rawlinson and Sambridge, 2004a, 2004b; de Kool et al., 2006; Rawlinson and Urvoy, 2006]. FMM is a grid-based finite difference scheme to solve the eikonal equation. Within FMTOMO, the multistage application of FMM allows traveltimes for phases composed of any number of reflection or refraction events to be calculated [de Kool et al., 2006]. Synthetic traveltimes were then compared with observational data. Analyses of the spatial distribution of traveltime residuals and raypaths were then used to adjust the model volume to reduce misfit (Figure 4a). This procedure was carried out according to a strategy outlined below, and repeated until the fit could not be improved.

\subsection{Model Assumptions and Construction Steps}

[17] Our forward model was constructed following a strategy in which the best constrained and most densely sampled regions were analyzed first. We then adjust layer boundaries in 3-D to best fit the 
traveltimes of all recorded phases, assuming the same layer velocities, and taking into account existing knowledge of the subduction zone. The forward modeling sequence was as follows.

[18] 1. The water layer was defined on the basis of bathymetric data from the National Institute of Water and Atmospheric Science (NIWA).

[19] 2. Sedimentary layers were defined on the basis of stacking velocities and reflection traveltimes determined from RAU07 MCS data [Fugro Seismic Imaging, 2007; Sutherland et al., 2009], and from the results of forward modeling refracted and reflected arrivals recorded by ocean bottom seismometers during the MANGO experiment [Scherwath et al., 2010]. These layers were not adjusted during the fitting procedure and represent a crude approximation to the very rich MCS data set (see below).

[20] 3. Fore-arc basement velocity, Moho geometry, and mantle wedge velocity was estimated along profile RAU07-09. Profile RAU07-09 crosses line RAU07-05 and is in line with four onshore seismometers (Figure 2), and is thus the most densely sampled and best constrained profile that was acquired.

[21] 4. Fore-arc and subducting plate basement velocity, Moho geometry, and mantle wedge velocity was estimated along profile RAU07-05. The velocity structure beneath profile RAU07-05 is constrained by ocean bottom refraction and wide-angle reflection data [Scherwath et al., 2010]. Shots from this line were progressively incorporated into our model west, then east of this profile's intersection with RAU07-09 and were limited to those with origins within the Raukumara Plain (Figures 1 and 2).

[22] 5. Based upon analyses of refracted arrivals along profiles RAU07-05 and RAU07-09 we define the fore-arc basement velocity bounding values for the whole layer. Likewise, we define a mantle velocity at the Moho and a velocity gradient beneath.

[23] 6. In regions were the Moho is unconstrained by RAU07 reflection data, we adjust the Moho depth to fit all remaining arrivals from shots from the Raukumara Plain. Initial focus was on the strike profile RAU07-10, followed by dip profiles progressively farther offset from the Raukumara Peninsula (Figure 2). Raypaths for arrivals from the Raukumara Plain are less complicated than those originating east of Raukumara Basin, because they are entirely above the subduction interface.
[24] 7. We adjust the Moho depth of the subducting plate to fit arrivals from shots originating east of East Cape Ridge. We start at the eastern limit of profile RAU07-05, where shots are east of the surface trace of the plate boundary and the shallow structure is well constrained by MCS and $\mathrm{OBH} / \mathrm{S}$ data [Scherwath et al., 2010].

[25] 8. We adjusted layer boundary depths beneath the East Cape Ridge region (Figure 2). We define a relatively thick layer with velocities consistent with interpretation of $\mathrm{OBS} / \mathrm{H}$ data [Scherwath et al., 2010] and without coherent reflections from MCS data [Sutherland et al., 2009]. This layer makes up most of the fore-arc rock volume beneath the trench slope (Figure 6). We define a continuous smooth subduction interface that connects reflections at $<12 \mathrm{~km}$ [Scherwath et al., 2010] and 30-35 km [Sutherland et al., 2009] along line RAU07-05 and has an approximately cylindrical geometry. We define the position of the subducting plate Moho assuming the same crustal thickness as determined east of the plate boundary. Traveltime residuals are then fit by inclusion of a low-velocity prism positioned above the subduction interface and below up-tilted sedimentary and crustal layers modeled beneath Raukumara Plain. This layer is required to fit large ( $>2 \mathrm{~s}$ ) positive traveltime residuals (see auxiliary material).

\subsection{Model Limitations and Fit to Data}

[26] At the conclusion of forward modeling, the RMS of residuals is $0.568 \mathrm{~s}$ and the residuals are close to normally distributed (Figure $4 b$ ). Although the fit to data could be improved by increasing the number or complexity of layers, the ray coverage does not justify a more complex model. A 3-D grid of ray density was constructed and used to discriminate between constrained and unconstrained regions in plots of model results (Figures 5, 6a, and $6 b$ ).

[27] We compared synthetic reflection times to our layer boundaries with reflected arrivals observed on the MCS data (see details in auxiliary material). We assume that the layer boundaries have produced the reflections and analyze the differences between observed and calculated two-way traveltimes. The fit of the shallowest interface, at the base of the Neogene sedimentary sequence (Megasequence $\mathrm{Z}$ in the work by Sutherland et al. [2009]), has a

\footnotetext{
${ }^{1}$ Auxiliary materials are available in the HTML. doi:10.1029/ 2010 GC003137.
} 


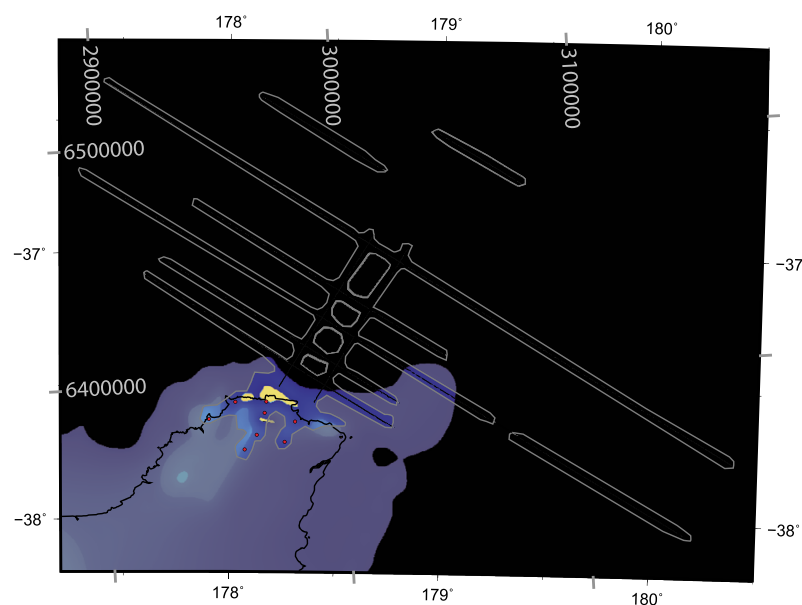

DEPTH $=0.5 \mathrm{~km}$

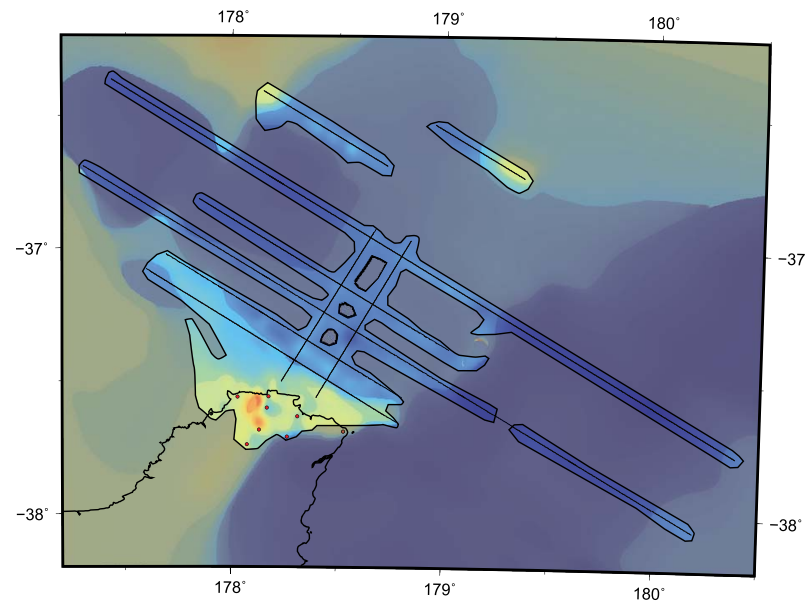

DEPTH $=5.0 \mathrm{~km}$

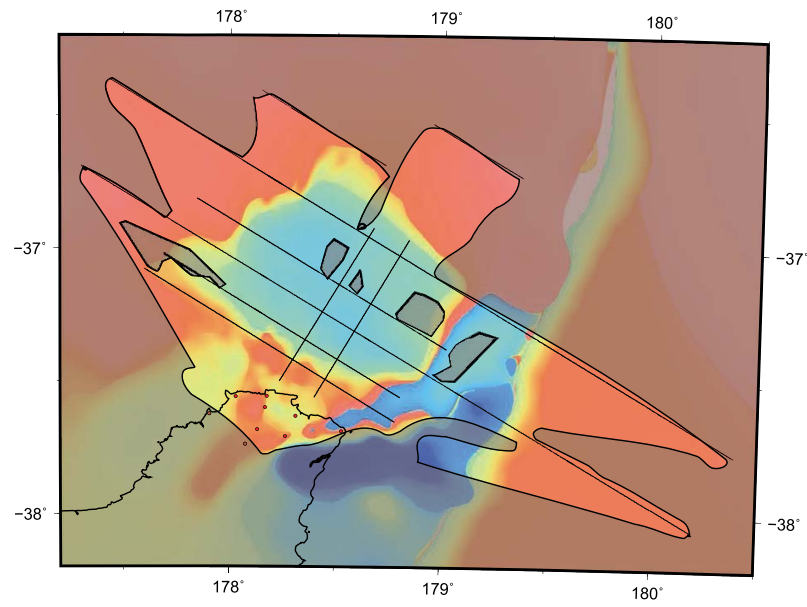

$\mathrm{DEPTH}=10.0 \mathrm{~km}$

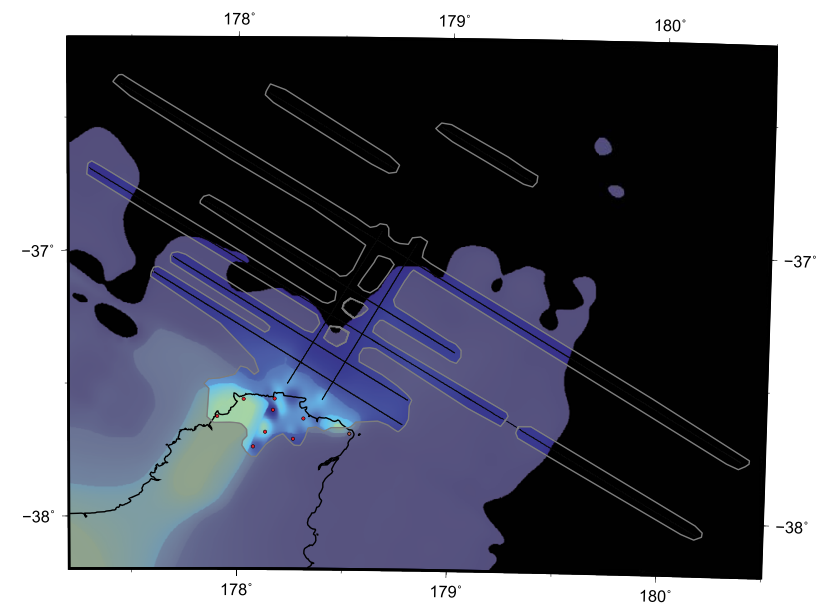

DEPTH $=2.0 \mathrm{~km}$

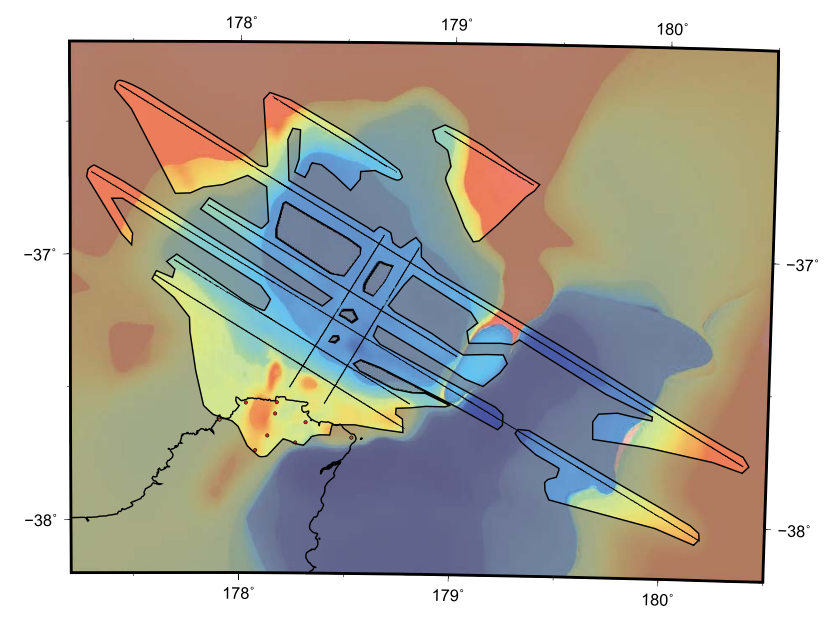

$\mathrm{DEPTH}=7.5 \mathrm{~km}$

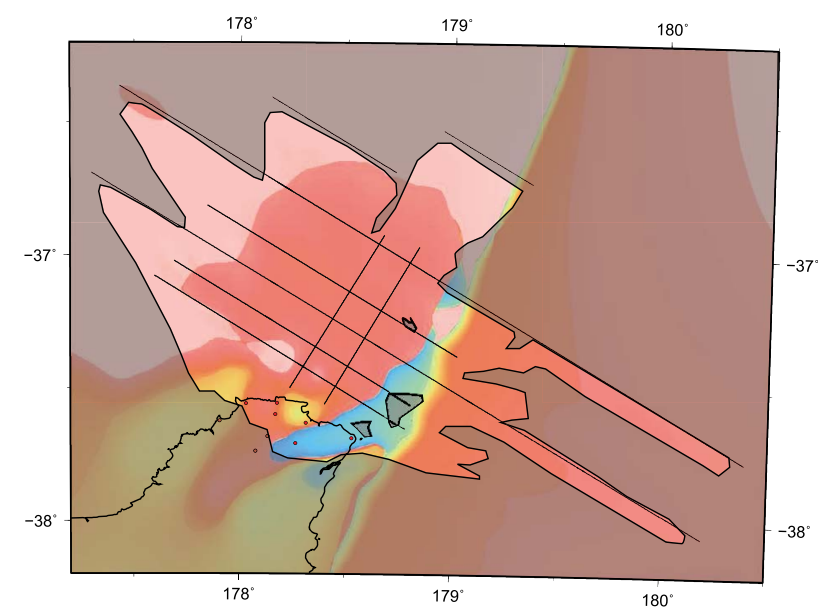

$\mathrm{DEPTH}=15.0 \mathrm{~km}$

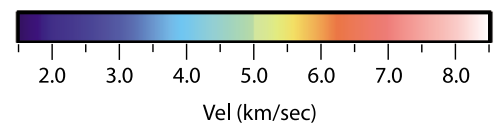

Figure 5 

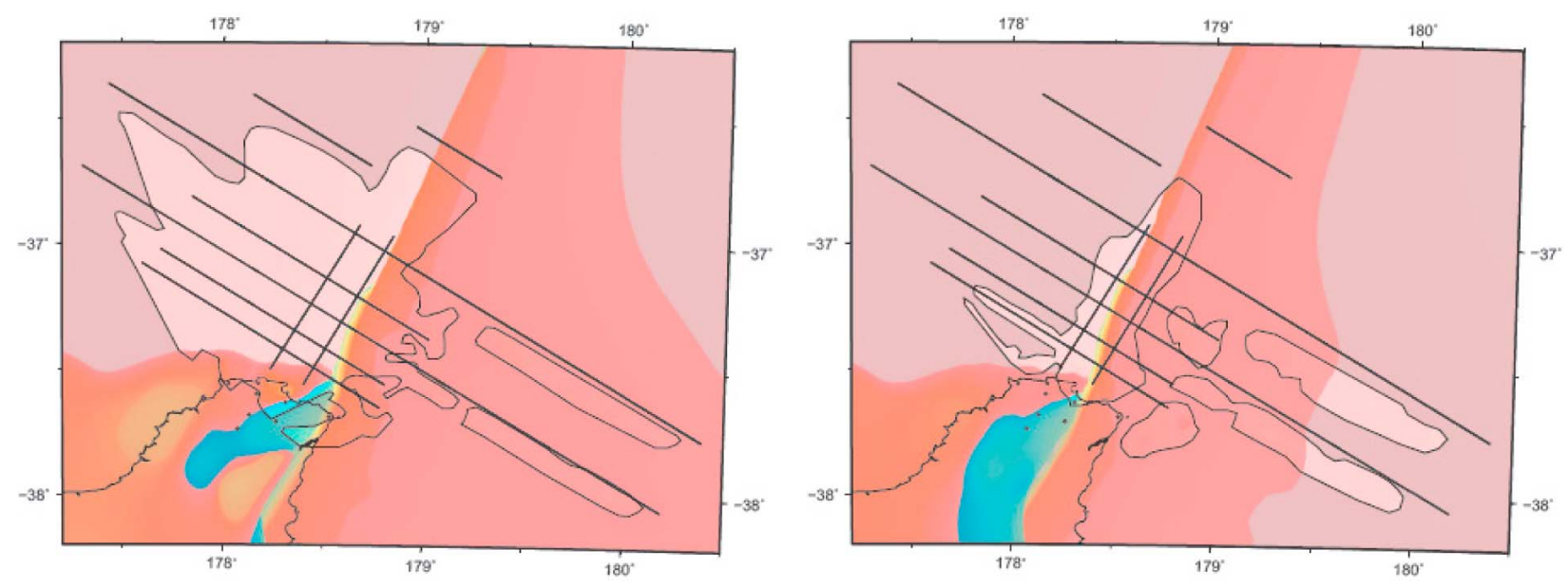

DEPTH $=20.0 \mathrm{~km}$

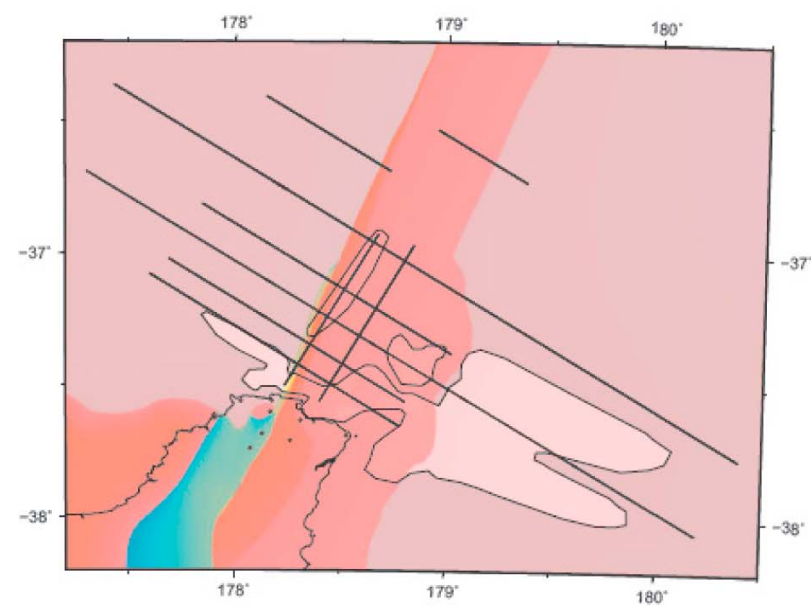

$\mathrm{DEPTH}=25.0 \mathrm{~km}$

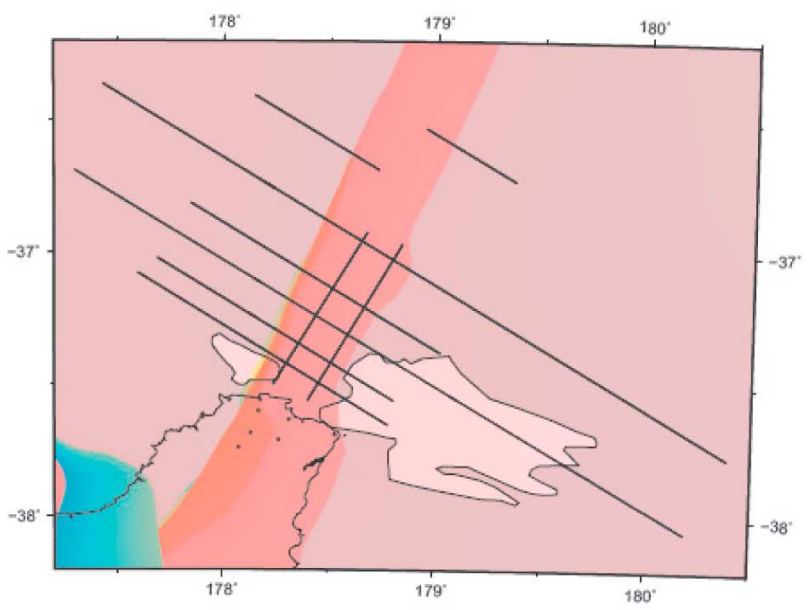

$\mathrm{DEPTH}=30.0 \mathrm{~km}$

DEPTH $=35.0 \mathrm{~km}$

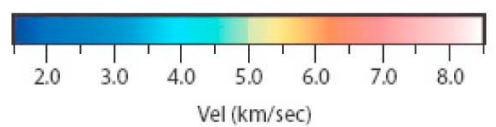

Figure 5. (continued)

standard deviation of $86 \mathrm{~ms}$, equivalent to a velocity precision of $\sim 0.06 \mathrm{~km} \mathrm{~s}^{-1}$. For reflections from the base of the Raukumara Basin sedimentary layer, which is over a depth range of 6 to $13 \mathrm{~km}$, the standard deviation is $265 \mathrm{~ms}$. This converts to a precision in the mean velocity of basinal sediments of $\pm 0.10 \mathrm{~km} \mathrm{~s}^{-1}$ These values quantify misfit introduced by the very small number of parameters that we use to define our velocity model and approximate the very rich data set derived from stacking velocities at shallow depths $(<5 \mathrm{~km})$, and the greater uncertainty in defining reflections and velocities at the base of the sedimentary layer.

[28] Several MCS lines have clearly identified reflection events that we interpret as Moho reflections. These reflections are an independent test of the model because they were not used as input. The

Figure 5. Depth slices (as labeled) displaying the distribution of $P$ wave velocities $\left(\mathrm{V}_{\mathrm{p}}\right)$ within the final forward model. Darker areas represent regions not sampled by wide-angle seismic data. Black lines offshore display RAU07 reflection profiles and the source of interpreted arrivals. Coastline of the Raukumara Peninsula displayed in black. New Zealand Map Grid coordinates provided within the $0.5 \mathrm{~km}$ depth slice. Note the prevalence of low velocities in the East Cape Ridge region. 


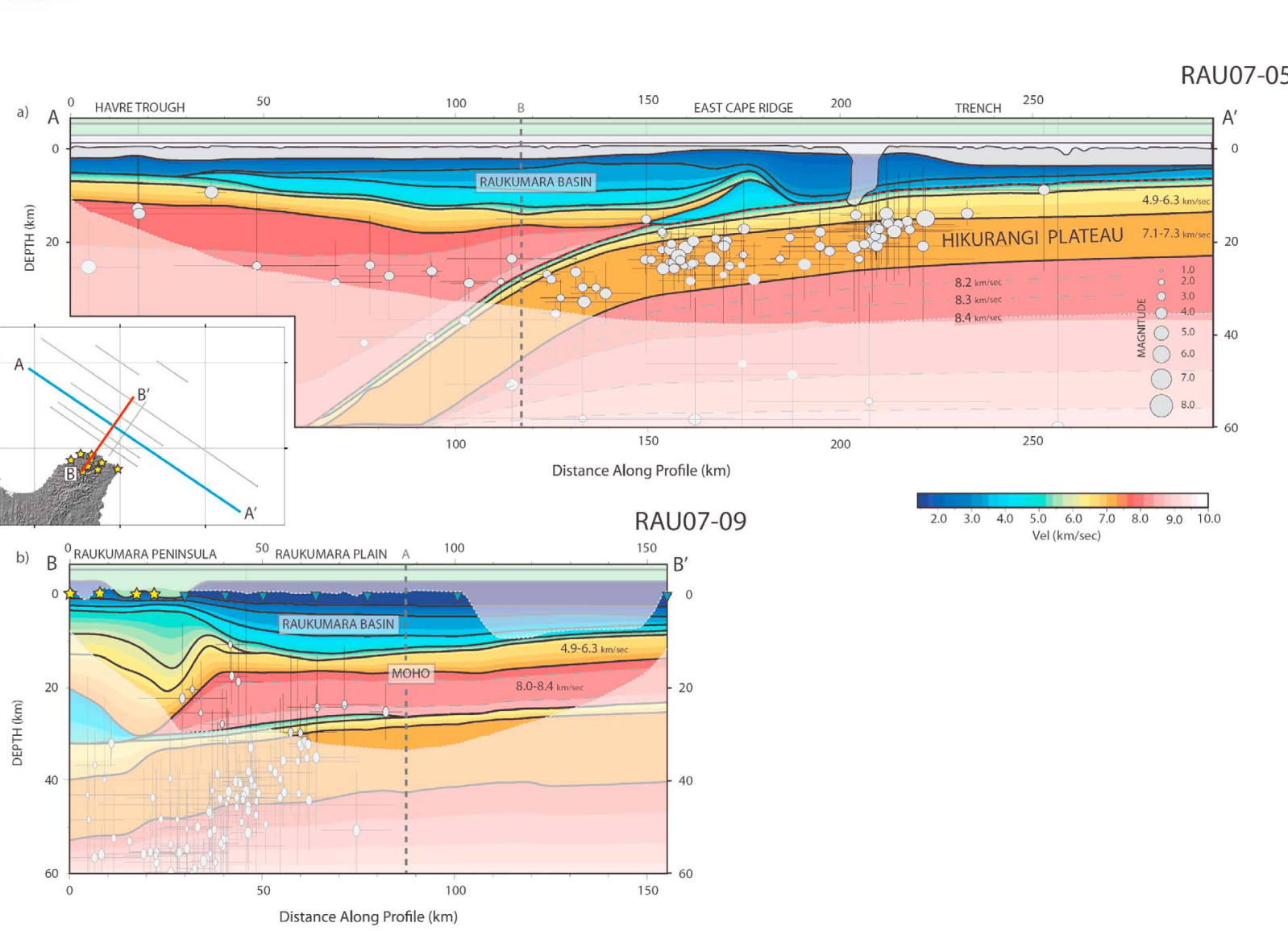

Figure 6. Cross sections along (a) RAU07-05 (blue line, inset) and (b) RAU07-09 (red line, inset) and its onshore projection displaying the dip and strike parallel $V_{p}$ structure through the velocity forward model. The intersection of these profiles is marked by a thick dashed line. Masked areas illustrate regions not sampled by seismic data. Earthquakes with $\mathrm{Mw}>2$ and hypocenters within $5 \mathrm{~km}$ of each profile are plotted and scaled to magnitude. Earthquake locations are downloaded from GeoNet (http://www.geonet.org.nz) and are not located using this velocity model.

standard deviation of differences between observed and modeled two-way times is $325 \mathrm{~ms}$.

[29] To analyze the trade-off and estimate the uncertainty in both crustal velocity and mantle wedge velocity, we performed a tomographic velocity inversion for the mantle layer, assuming that the two-way time of Moho reflectors constrains the total traveltime through the crust; that is, we impose Moho reflection events as a constraint on the model. The mantle wedge velocity estimated by this inversion is $8.30 \pm 0.25 \mathrm{~km} \mathrm{~s}^{-1}$ (details in auxiliary material).

[30] The low-velocity prism we model beneath East Cape Ridge and the Raukumara Peninsula is constrained by $\sim 4500$ raypaths. Although the unidirectional geometry of raypaths allow for a trade-off between velocity and geometry, the RAU07 reflection profiles [Sutherland et al., 2009], RV Sonne refraction data [Scherwath et al., 2010], and earthquake studies [Eberhart-Phillips and Reyners,
1999; Reyners et al., 1999] provide additional constraints on the geometry and properties of this layer. The velocity within the low-velocity prism is most reliably constrained by arrivals at Pakira from shots at the eastern end of RAU07-07. These raypaths are almost entirely located within the low-velocity prism and we calculate an average velocity for these arrivals of $\sim 4.2 \mathrm{~km} \mathrm{~s}^{-1}$ over raypaths of $\sim 65 \mathrm{~km}$ that reach a maximum depth of $\sim 18 \mathrm{~km}$ (see Figure $\mathrm{S} 10 \mathrm{~d}$ in Text S1 in the auxiliary material).

\section{Results}

\subsection{Regional 3-D Velocity Structure}

[31] The Raukumara Basin is a low-velocity region (1.9-4.9 $\mathrm{km} \mathrm{s}^{-1}$ ) reaching a maximum depth of $12.5 \mathrm{~km}$ (below sea level) beneath the southern Raukumara Plain (Figures 5, 6a, and 6b). The approximately triangular geometry of the basin is spatially correlated with a $-150 \mathrm{mGal}$ free-air 
a)

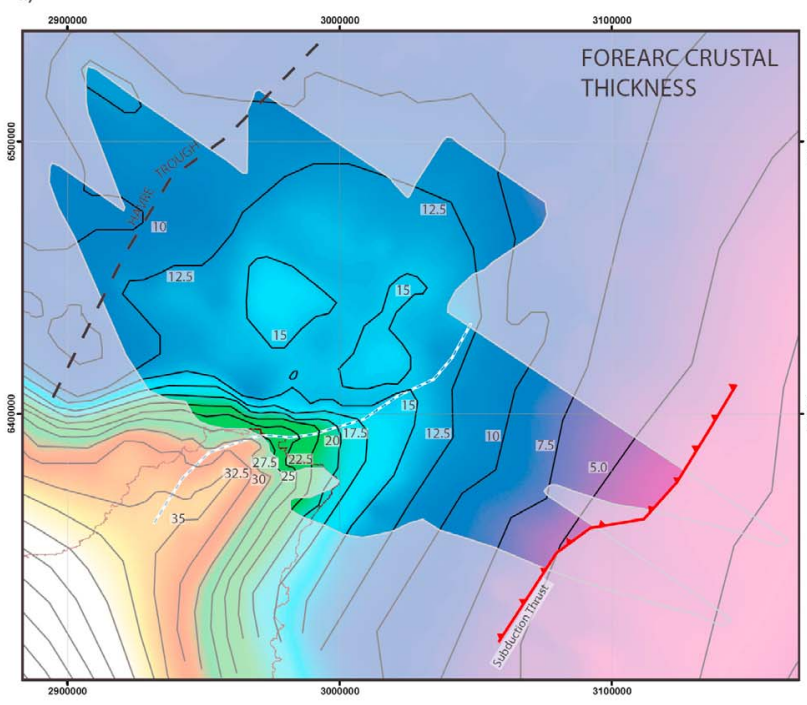

b)

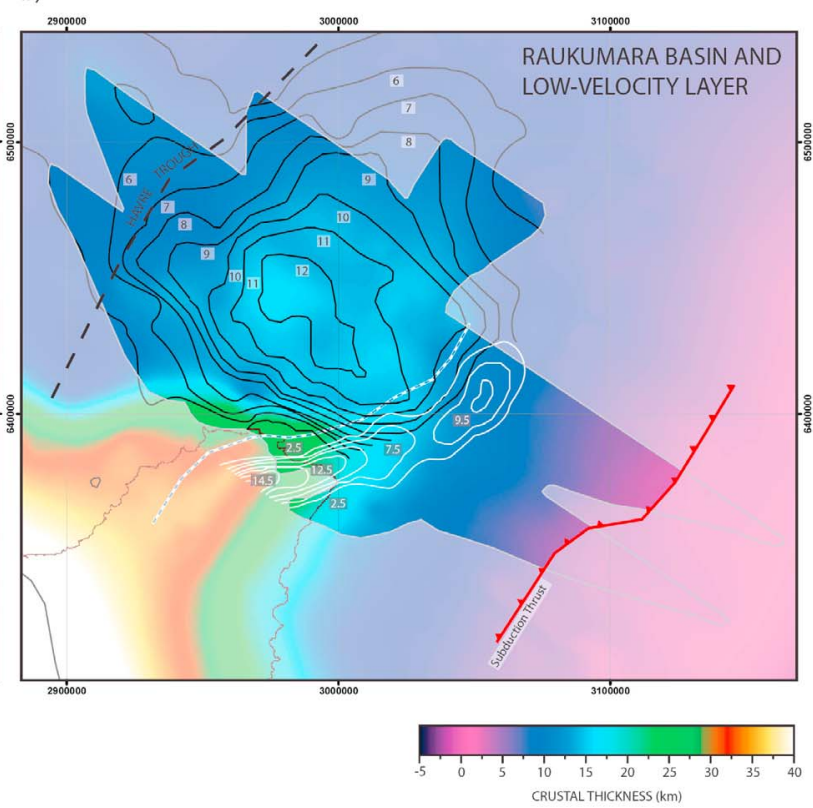

Figure 7. Maps displaying (a) fore-arc crustal thickness (basin sediments + basement) and (b) the discrete components of the fore-arc crustal column in this region. In Figure 7b, depth contour of the base of Raukumara Basin sediments is displayed in black (values labeled in $\mathrm{km}$ ). White contour displays the thickness (labeled in $\mathrm{km}$ ) of the low-velocity (3.5-5.0 $\mathrm{km} \mathrm{s}^{-1}$ ) prism modeled between fore-arc basement and the top of the subducting slab (section 5.1). Basement thickness can be calculated by subtracting either of these components from the total crustal thickness depicted in Figure 7a. Surface trace of the subduction thrust displayed in red. White and blue dashed line illustrates the point of intersection between the Moho and the subduction interface. Note the geometrical correlation between the intersection lineation between the subducting slab and the Moho and the arcward edge of the low-velocity prism. Faded area denotes regions where the fore arc is not sampled at any depth.

gravity anomaly (Figure 2) and is resolved on the basis of a velocity contrast between sedimentary basin fill $\left(1.9-4.9 \mathrm{~km} \mathrm{~s}^{-1}\right)$ and fore-arc basement (4.9-7.2 $\left.\mathrm{km} \mathrm{s}^{-1}\right)$. The northern boundary of Raukumara Basin is not constrained by existing seismic reflection or refraction data. South and east of the central basin, sedimentary and basement layers tilt upward toward the Raukumara Peninsula and East Cape Ridge, respectively, and are progressively underlain by a low-velocity $\left(3.5-5.0 \mathrm{~km} \mathrm{~s}^{-1}\right)$ triangular prism localized beneath the topographic crest (Figures 6a and 6b).

[32] The East Cape Ridge marks the eastern boundary of Raukumara Basin. The upper 5-7 km of the ridge is modeled with velocities from 1.9 to $4.9 \mathrm{~km} \mathrm{~s}^{-1}$ associated with sedimentary layers, which shallow from the central basin (Figure 6a). Basement velocities (4.9-7.2 $\mathrm{km} \mathrm{s}^{-1}$ ) are modeled at intermediate depths, which appear uplifted above the low-velocity $\left(3.5-5.0 \mathrm{~km} \mathrm{~s}^{-1}\right)$ prism mentioned above. The eastern limit of subbasement low velocities $\left(3.5-5.0 \mathrm{~km} \mathrm{~s}^{-1}\right)$ coincides with the intersection of the Moho with the subducting slab, and thus the trenchward limit of the fore-arc mantle wedge (Figure $7 \mathrm{~b}$ ). The arcward migration of the East Cape Ridge crest (and low-velocity prism) within the continental shelf(Figures 1 and 2), occurs concomitant with an increase in Moho depth (section 5.2) between the Raukumara Plain and the Raukumara Peninsula (Figures $7 \mathrm{~b}$ and 8). These spatial associations underpin the 3-D application of a cyclical crustal dynamic [Sutherland et al., 2009] that is hypothesized to result in lower crustal underplating (section 6.1).

[33] Following Scherwath et al. [2010], the crust of the subducting slab is modeled as two layers with velocities from 4.9 to $6.7 \mathrm{~km} \mathrm{~s}^{-1}$ and $7.1-7.3 \mathrm{~km} \mathrm{~s}^{-1}$. We model a combined thickness of 17-19 km (Figure 6a). At the trench at the eastern end of line RAU07-05, the top of the subducting slab is modeled dipping NW at $2-5^{\circ}$ and is overlain by $\sim 5.0 \mathrm{~km}$ of low-velocity material $\left(1.9-4.0 \mathrm{~km} \mathrm{~s}^{-1}\right)$. Of this sequence, the upper $\sim 1-2 \mathrm{~km}$ is composed of debris locally sourced from the collapsing trench slope and Ruatoria Debris Avalanche [Collot et al., 2001; Lewis et al., 2004], $\sim 1 \mathrm{~km}$ is interpreted as deep- 


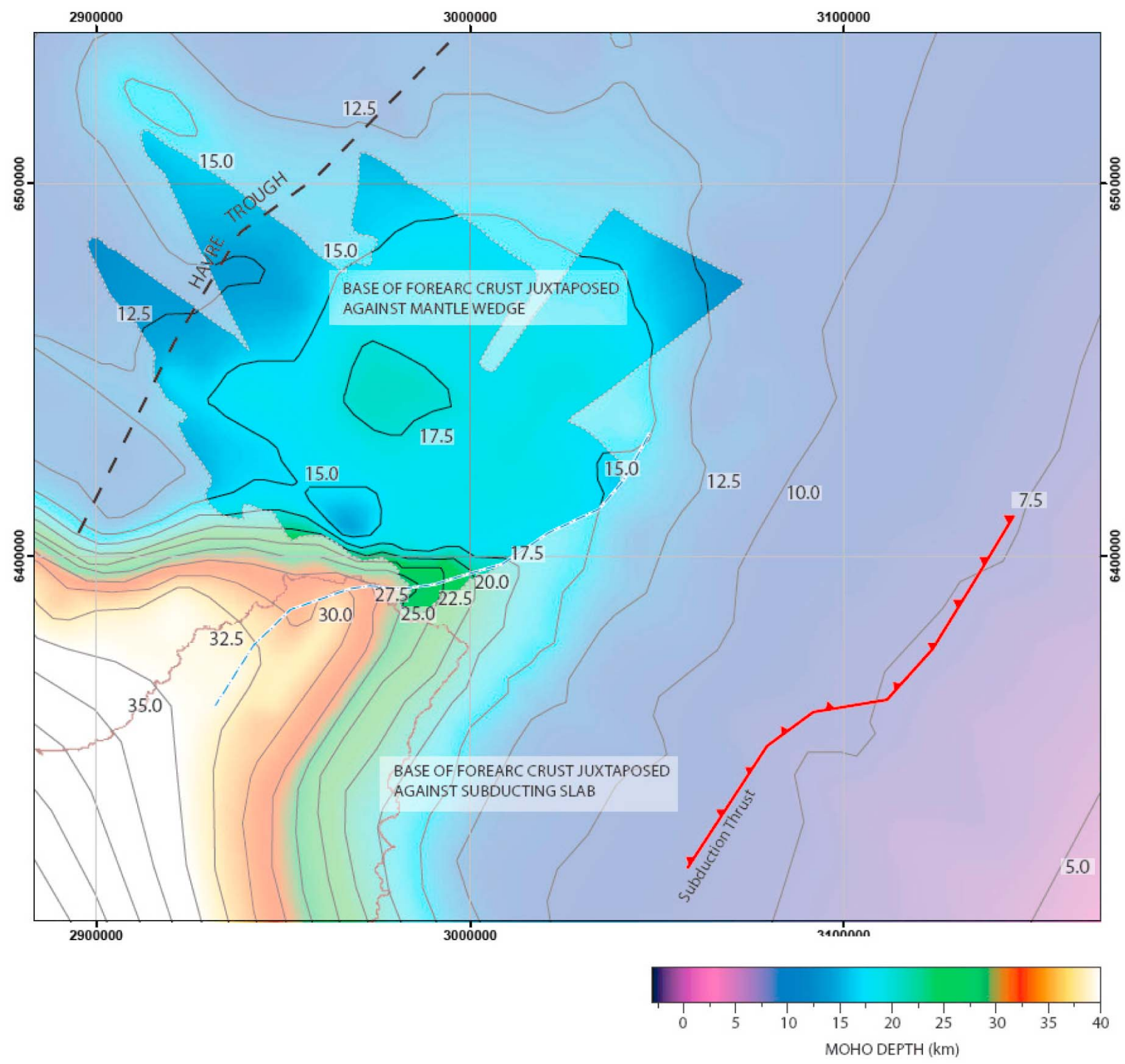

Figure 8. Map displaying the depth to the base of fore-arc crust (Moho). Contours are at $2.5 \mathrm{~km}$ intervals (as labeled). White and blue dashed line illustrates the point of intersection between the Moho and the subduction interface. Surface trace of the subduction thrust displayed in red. Faded area displays regions where the Moho is not constrained by onshore-offshore seismic data.

ocean sediments, and the remainder is the upper volcaniclastic layers of the Cretaceous large igneous province [Davy et al., 2008]. At the eastern end of line RAU07-03 there is a uniform layer of deepocean sediments $\sim 0.7 \mathrm{~km}$ thick on the subducting plate. The upper $10 \mathrm{~km}$ of the subducting mantle lithosphere is sampled by arrivals from the eastern regions of RAU07-05 and RAU07-03 (Figure 9), and is modeled with a velocity in the range 8.1$8.4 \mathrm{~km} \mathrm{~s}^{-1}$ (Figure 6a).

\subsection{Structure of the Moho}

[34] Southeast along strike between the Raukumara Plain and the Raukumara Peninsula, velocity forward models resolve a $>10 \mathrm{~km}$ increase in depth to the fore-arc Moho (Figures $6 \mathrm{~b}$ and 8). The Moho beneath the Raukumara Plain is approximately planar and modeled between 15 and $17.5 \mathrm{~km}$ depth [Scherwath et al., 2010; this study]. In contrast, the western Raukumara Peninsula is characterized by a 


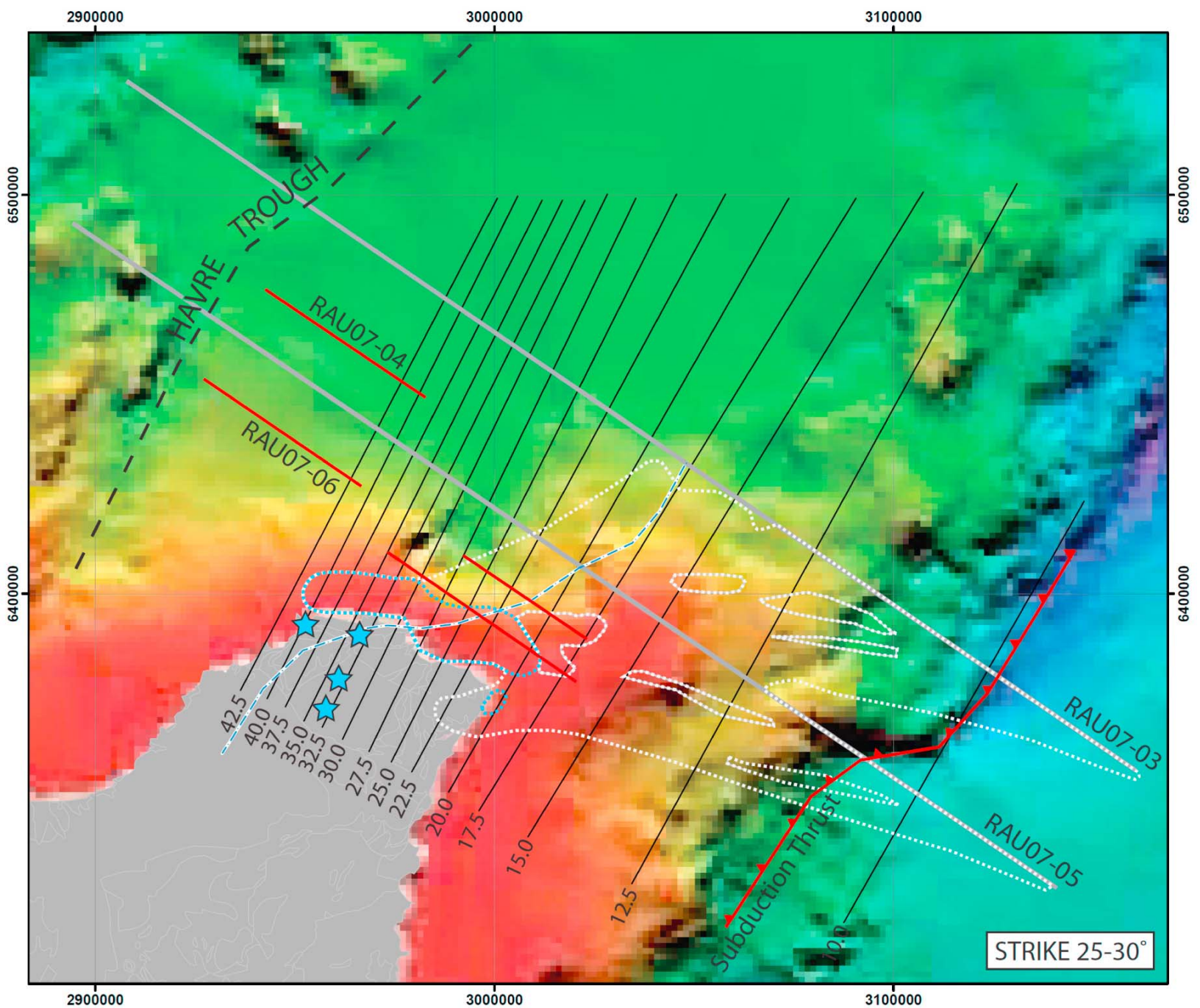

Figure 9. Bathymetric map displaying contours of the subduction interface (as labeled). Dashed white line demarcates regions where the plate interface is constrained by onshore-offshore seismic data. Dashed blue areas show regions where the plate interface is sampled by wide-angle reflections. Red lines and blue stars denote the line positions and recording stations of wide-angle plate interface reflections. White and blue dashed line illustrates the point of intersection between the subduction interface and the fore-arc Moho.

Moho depth $>25 \mathrm{~km}$ [Reyners et al., 1999; this study]. The geometry of the transition in Moho depth trends west-east and is inversely correlated with topography (Figures 1 and 8). Moho structure is constrained west of East Cape Ridge within the offshore region landward of RAU07 profiles.

[35] Around the perimeter of the Raukumara Plain, the Moho is modeled shallowing from its position within the central basin $(\sim 17 \mathrm{~km})$, occupying depths of $<12.5 \mathrm{~km}$ within the Havre Trough, $<15 \mathrm{~km}$ within the northern Raukumara Plain and 10-15 km within the East Cape Ridge region
(Figure 8). Within the Havre Trough, a region of increased Moho depth $(12.5$ to $>15 \mathrm{~km})$ is correlated with a bathymetric trough and a break in the volcanic arc (Figures 1 and 8).

\subsection{Structure of the Subduction Interface}

[36] The geometry of the subduction interface (Figure 9) is constrained by deep reflections from RAU07 MCS reflection data and both refracted arrivals and wide-angle reflections from onshoreoffshore seismic data. The raypaths of these arri- 
vals define a wedge extending east from the eastern Raukumara Basin along RAU07-03 and RAU07-05. The plate interface is sampled by refracted rays along two profiles positioned landward of RAU07-05 and RAU07-03, and by wide-angle reflections, which sample the subduction interface beneath the continental shelf of the northern Raukumara Peninsula (Figure 9).

[37] The strike of the subduction thrust is $25-30^{\circ}$ and dip increases from 2 to $5^{\circ}$ east of the trench to $>25^{\circ}$ beneath the central Raukumara Basin. Two distinct increases in dip are observed east $\left(\sim 2^{\circ}\right.$ increase) and west $\left(\sim 5^{\circ}\right.$ increase $)$ of East Cape Ridge along RAU07-05, which are correlated with regions of increased seismicity within the subducting slab (Figure 6a). The locus of points of intersection between the subduction interface and the fore-arc Moho is located on the western flank of East Cape Ridge and migrates arcward southeast along strike, coincident with the increase in Moho depth beneath the continental shelf (Figure 8).

\section{Discussion}

\subsection{Crustal Underplating at East Cape Ridge}

[38] We use our 3-D velocity model to assess previous suggestions of crustal growth at East Cape Ridge [Sutherland et al., 2009] and we determine the volume of the velocity anomaly that is thought to be associated with underplated material [Scherwath et al., 2010] to constrain local rates of underplating.

[39] Gravitational collapse and mass wasting of the trench slope adjacent to East Cape Ridge is evidence for ongoing subduction erosion [Collot and Davy, 1998], but the net removal of fore-arc material by such a process would cause a trenchward advection of the fore arc and the oldest arc volcanoes [Lallemand, 1995]. However, western Raukumara Basin and the active arc is clearly imaged with high-fold seismic reflection data and no relict arc volcanoes are observed, so it is concluded that there has been no net decrease in the volume of the forearc wedge via tectonic erosion since ca. $22 \mathrm{Ma}$ [Sutherland et al., 2009]. In addition, and contrary to suggestions of net crustal erosion at this location [von Huene and Scholl, 1991; Collot and Davy, 1998; Clift and Vannucchi, 2004], stratal relationships between shallow second-order seismic stratigraphic sequences reveal a southeast-northwest migration of the Neogene Raukumara Basin depocenter [Sutherland et al., 2009]. This migration is consistent with a net increase in volume of the fore- arc wedge, and specifically, the protuberant growth of East Cape Ridge and the Raukumara Peninsula. The morphology of young onshore deposits and geomorphic surfaces is also consistent with a pattern of broad Quaternary uplift inferred to have been caused by underplating [Litchfield et al., 2007]. The highly faulted and indurated physiography of the trench slope eliminates frontal accretion as a mechanism of achieving crustal growth and hence lower crustal underplating is the most likely alternative.

[40] A crustal low-velocity region has previously been identified beneath the offshore East Cape Ridge [Scherwath et al., 2010], the onshore Raukumara Peninsula [Reyners et al., 1999], and the Kaimanawa mountain range farther south [Reyners et al., 2006]. Our 3-D velocity model constrains the offshore prismatic geometry of this low-velocity $\left(3.5-5.0 \mathrm{~km} \mathrm{~s}^{-1}\right)$ body and confirms that it underlies the topographic crest of the fore arc. Thus, we agree with previous suggestions that this prism may consist of underplated sedimentary and crustal material, and that it may be driving the local rock uplift that is the cause of the topographic crest and Neogene stratigraphic tilting adjacent to East Cape Ridge and Raukumara Peninsula [Sutherland et al., 2009].

[41] The deformation pattern that produces this fore-arc architecture and pattern of uplift is proposed to have a cyclical kinematic [Sutherland et al., 2009]. Sediments on the downgoing plate are incorporated with material tectonically eroded from the toe of the trench slope into a subduction channel located above the subducting slab (Figure 10). Accompanying subduction, this material is transported arcward and downward to a position near the fore-arc Moho. In the lower crust, the density contrast between subducted sedimentary and crustal material $\left(\sim 2.3-2.7 \mathrm{~g} / \mathrm{cm}^{3}\right)$ and the mantle wedge $\left(\sim 3.4 \mathrm{~g} / \mathrm{cm}^{3}\right)$ prevents further subduction. The material in the subduction channel is weakened by temperature and fluid overpressure, and hence accreted across the subduction thrust to the upper plate, driving local rock uplift. Progressive uplift causes the trench slope to steepen above its critical angle of stability and gravitational collapse occurs. Trench slope collapse takes place both arcward and trenchward of the locus of underplating, with trenchward collapse creating the highly faulted trench slope and returning material to the subduction front completing the cycle (Figures 10c and 10d).

[42] The general increase in density with depth, and the position of the Moho in particular, is hypothesized to limit the downdip width of the subduction channel. The increase $(>10 \mathrm{~km})$ in Moho depth 

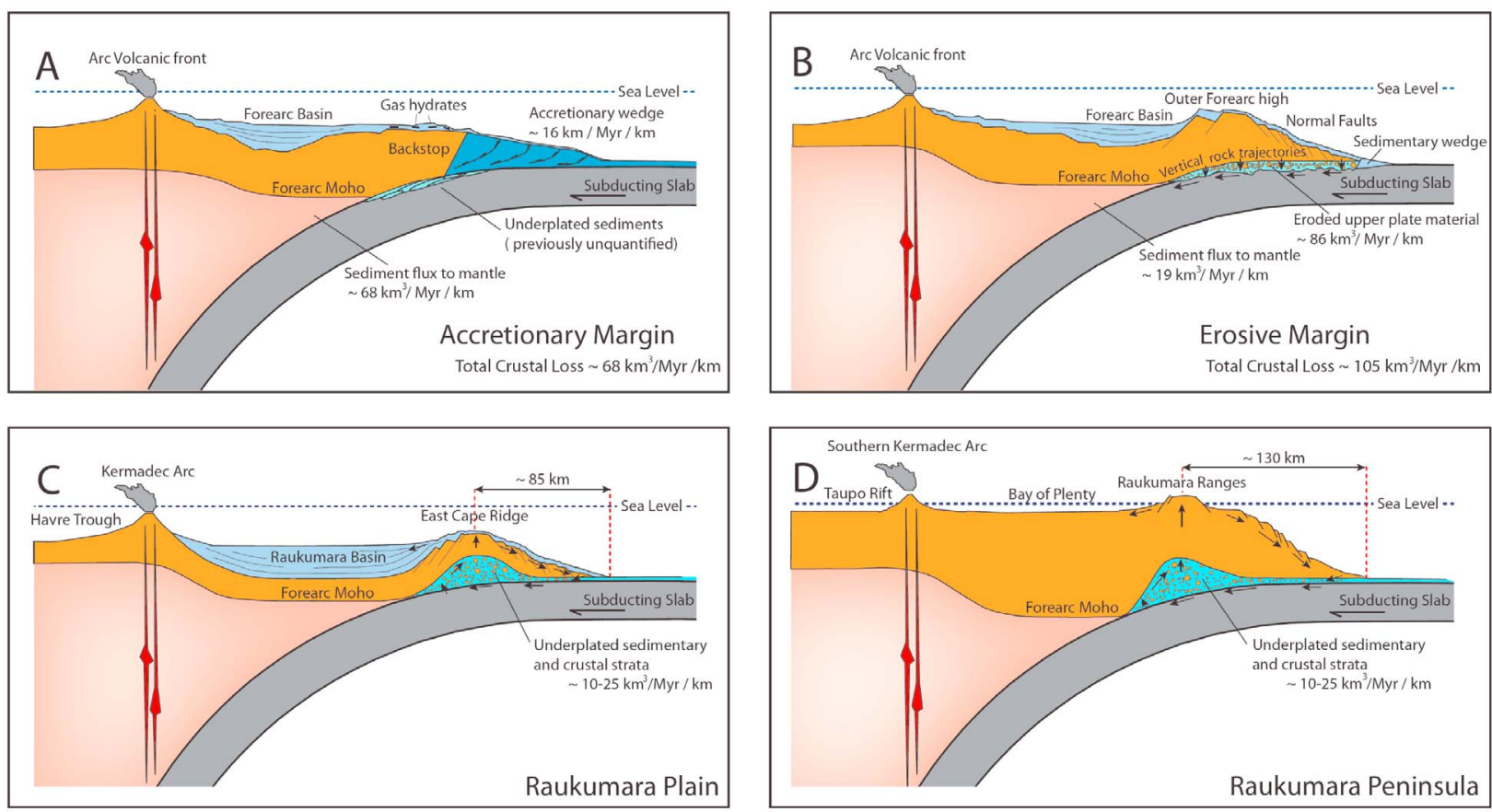

Figure 10. Schematic cartoon illustrating the features common to the two basic types of convergent margin presented within Clift and Vannucchi [2004]. (a) Accretionary and (b) erosive/nonaccretionary. The cyclical underplating kinematic proposed for margins displaying morphological and structural characteristics consistent with subduction erosion and stratigraphic evidence for zero net balance or a net increase in the volume of the fore-arc wedge (see section 6.1) beneath the (c) East Cape Ridge and (d) Raukumara Peninsula (modified from Sutherland et al. [2009]). Note the difference between the location of underplating and uplift relative to the trench between the two regions. This difference suggests that the Moho modulates the underplating process, effectively limiting the distance (and depth) subducted material can remain within the subduction channel before being accreted to the upper plate. Arrows denote hypothesized particle motion paths.

between the Raukumara Plain and Raukumara Peninsula (Figure 8) thus provides a viable explanation for the along-strike variation in offset between the trench and the topographic crest (Figures $1,10 \mathrm{c}$, and 10d). At margins where the rate of crustal underplating exceeds the rate of tectonic erosion, the fore-arc crust will grow and thicken, the Moho will deepen and the locus of crustal underplating will migrate away from the trench, as will its effect on surface topography. We hypothesize that the

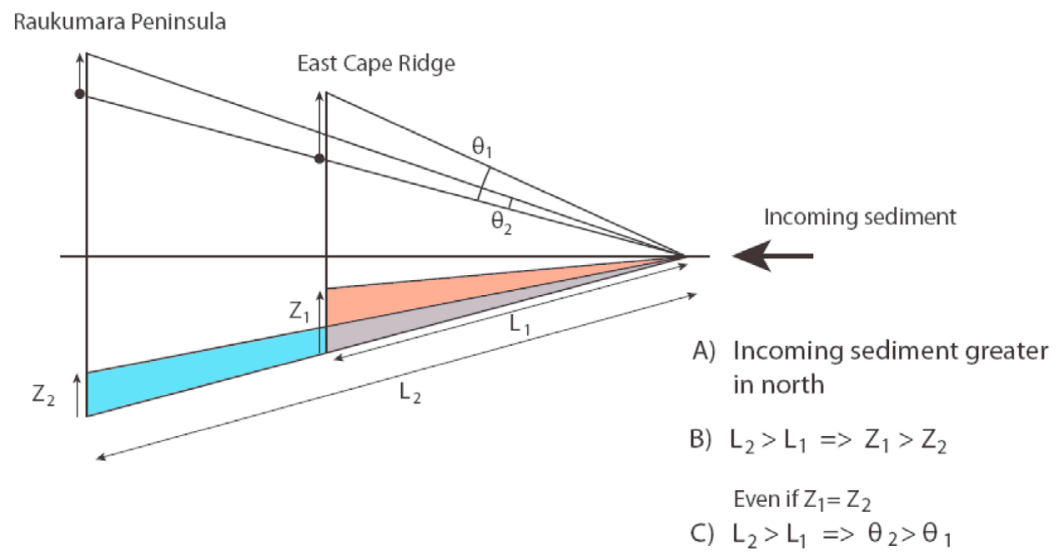

Figure 11. Cartoon illustrating the influence the downdip length of the subduction channel exerts on rates of uplift and angular increase in the overlying trench slope (see section 6.1). The shorter baseline adjacent to the Raukumara Plain results in underplated sediment being distributed over a smaller (thicker) area and, independent of differential uplift, enhances rates of angular increase. 
relatively shallow Moho beneath the Raukumara Plain results in higher rates of underplated rock uplift at East Cape Ridge than onshore because the shorter downdip length of the subduction channel causes underplated material to be distributed over a narrower area. The shorter baseline $\left(\mathrm{L}_{1}\right.$ in Figure 11) would also give rise to higher rates of trench slope steepening, if rock uplift and hence (transiently) surface uplift rates were the same. These effects are compounded further at the northern Hikurangi margin by higher rates of sediment supply adjacent to East Cape Ridge. We suggest that a combination of these factors explain why the intensity of trench slope faulting and collapse increases so dramatically to the north of Raukumara Peninsula [Collot and Davy, 1998]. Our model implies that trench slope collapse tectonically exhumes material at East Cape Ridge, and hence the rate of surface uplift at the crestline is less than the rate of rock uplift. Surface uplift rates may be higher onshore, because of erosion, even though underlying rock uplift rates may be less. This hypothesis may be tested in future by comparing thermochronologic data with surface uplift values determined from dated erosion surfaces.

[43] Volumes of the low-velocity prism (minimum) and the fore-arc wedge trenchward of the slabMoho intersection (maximum) determined from our $3-\mathrm{D}$ velocity model lead us to estimate a rate of lower crustal underplating of $10-25 \mathrm{~km}^{3} \mathrm{Ma}^{-1} \mathrm{~km}^{-1}$.

Figure 12. (a) Map displaying the thickness of lowvelocity material resolved using a threshold value of $-0.6 \mathrm{~km} \mathrm{~s}^{-1}$ (see section 6.2). Red line marks the point of intersection between the subducting slab and fore-arc Moho. Dashed line marks the boundary between regions constrained by our onshore-offshore forward model (north) and the tomographic grids of Reyners et al. [1999, 2006] (south). Bathymetric contours displayed at $500 \mathrm{~m}$ intervals. Thick black line marks the surface trace of the Hikurangi subduction thrust. Note that this is a rotated map projection. The scale is in meters, and New Zealand Map Grid coordinates are plotted and labeled on the map interior. (b) Topography across profile $\mathrm{A}-\mathrm{A}^{\prime}$ (dotted line in Figure 12a). (c) $P$ wave velocity along profile $\mathrm{A}-\mathrm{A}^{\prime}$ as constrained by earthquake tomography [Reyners et al., 1999]. Velocity contours labeled at $0.5 \mathrm{~km} \mathrm{~s}^{-1}$ intervals. Grey pluses mark model inversion nodes. Earthquake hypocenters for events occurring within $20 \mathrm{~km}$ of the profile and with $\mathrm{Mw} \geq 2$ marked by gray dots. Earthquake locations are from GeoNet and are not located using this velocity model. Solid black line gives the approximate geometry of the top of the subducting slab. Dotted lines show the region of anomalously low velocity resolved using threshold values from $-0.7 \mathrm{~km} \mathrm{~s}^{-1}$ (inner contour) to $-0.3 \mathrm{~km} \mathrm{~s}^{-1}$ (outer contour).
We assume that the volume of the velocity anomaly is entirely underplated material and that it accumulated over the last $22 \mathrm{Ma}$, which is the Cenozoic phase of subduction in this region.

\subsection{Rate and Mechanism of Underplating at the Northern Hikurangi Margin}

[44] We analyzed the geometry of the southward continuation of the prismatic low-velocity anomaly that we interpret as underplated material by con-
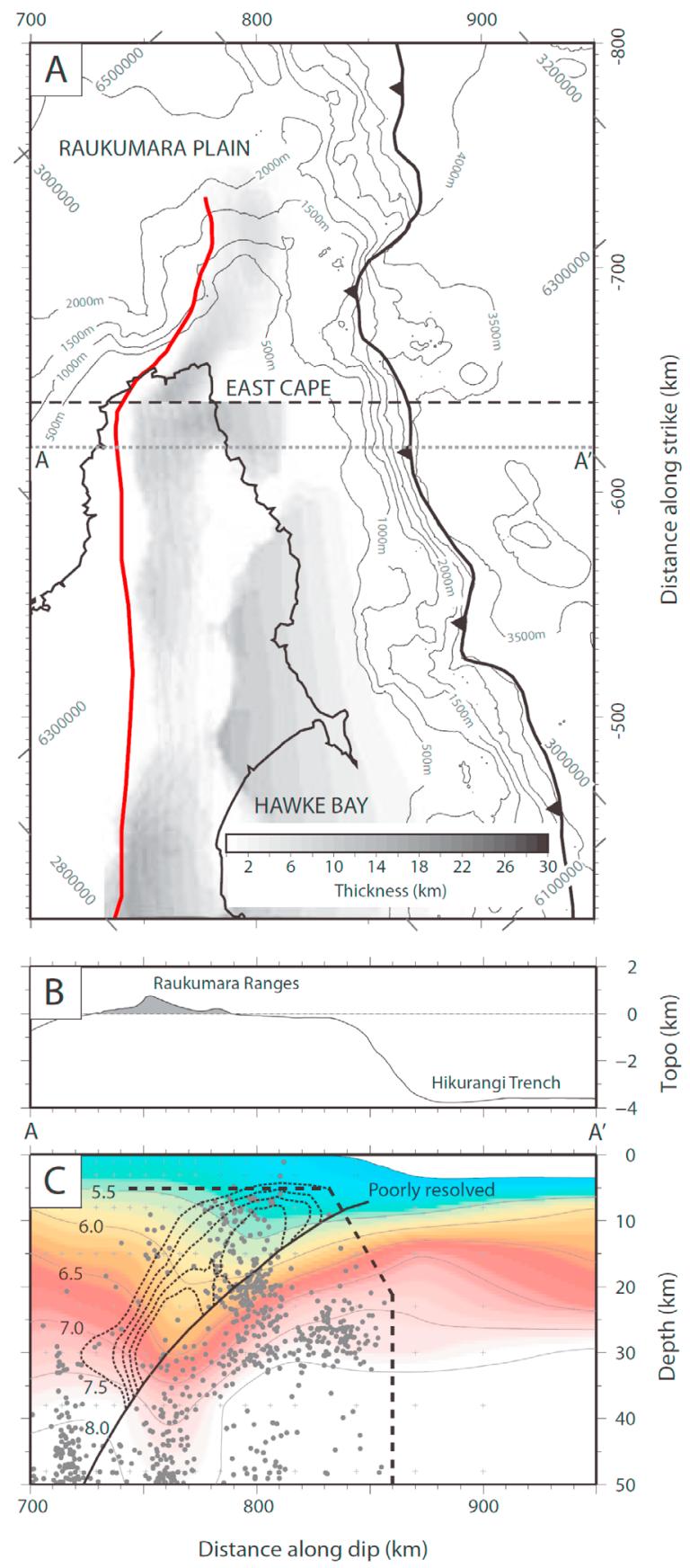
sidering our velocity model adjacent to published tomographic grids of $\mathrm{Vp}$ structure beneath Raukumara Peninsula and the central North Island [Reyners et al., 1999, 2006; D. Eberhart-Phillips, personal communication, 2010]. An average 1-D velocity profile was calculated, and then velocity anomalies were determined. We analyzed the 3-D distribution of negative-velocity anomalies by setting a threshold anomaly value and then we considered the geometry and properties of the volume with a velocity less than the threshold and above the subduction interface (Figure 12).

[45] We considered a range of threshold values. A threshold velocity anomaly of $-0.5 \mathrm{~km} \mathrm{~s}^{-1}$ results in a contiguous body that is clearly identified as a discreet low-velocity crustal root immediately above the subduction interface (see Figure 12 and auxiliary material). A threshold velocity anomaly value of $-0.7 \mathrm{~km} \mathrm{~s}^{-1}$ results in a much smaller enclosed volume, is discontinuous, and represents the largest average negative velocity anomaly. A velocity anomaly of $-0.3 \mathrm{~km} \mathrm{~s}^{-1}$ has a similar geometry to the $-0.5 \mathrm{~km} \mathrm{~s}^{-1}$ volume, but is larger and starts to enclose discreet isolated bodies that we interpret as natural variations in velocity associated with the different rock types accreted during Mesozoic subduction. This is confirmed by an analysis of rock samples from the Torlesse Supergroup (local basement rock) sampled in South Island, where they are unaffected by subduction tectonics: $60 \%$ of hand specimens subjected to pressures of $0.2-1.0 \mathrm{GPa}$ fall within a range of velocity of $+/-0.4 \mathrm{~km} \mathrm{~s}^{-1}$, but this would surely be lower if samples were mixed at seismic wavelengths [Christensen and Okaya, 2007].

[46] For the reasons given above, we use a threshold value of $-0.6 \mathrm{~km} \mathrm{~s}^{-1}$ and we limit our analysis to depths $>10 \mathrm{~km}$ because of resolution limitations of the grid that we are using. The volume of the low-velocity anomaly was added to that resolved farther north by our forward model, and the combined sum was used to calculate regional rates of lower crustal underplating along the northern half $(\sim 350 \mathrm{~km})$ of the Hikurangi margin over the last $22 \mathrm{Ma}$. Hence, we derive our best estimate for the rate of underplating during Cenozoic subduction to be $20 \mathrm{~km}^{3} \mathrm{Ma}^{-1} \mathrm{~km}^{-1}$. If we adopt a threshold value of $-0.5 \mathrm{~km} \mathrm{~s}^{-1}$, then we obtain what we consider to be a maximum value for the rate of underplating of $27 \mathrm{~km}^{3} \mathrm{Ma}^{-1} \mathrm{~km}^{-1}$. The magnitude of this velocity anomaly is greater than natural variations associated with Mesozoic rock type variability, with an additional $0.1 \mathrm{~km} \mathrm{~s}^{-1}$ to allow for the effects of percolating fluids, and still results in a contiguous volume above the subduction thrust (Figure 12c). A threshold value of $-0.7 \mathrm{~km} \mathrm{~s}^{-1}$ leads to a minimum estimate of $14 \mathrm{~km}^{3} \mathrm{Ma}^{-1} \mathrm{~km}^{-1}$.

[47] The magnitude of the velocity anomaly is likely related to the magnitude of the buoyancy anomaly and hence the driving force for accretion. This is because a general relationship exists between velocity and density [Christensen and Mooney, 1995; Brocher, 2005], and rock types are very similar at the Hikurangi margin: basement rocks are composed of clastic sediments that were accreted during Mesozoic time (Torlesse Supergroup), and the remaining (accreted) material is either tectonically reworked Torlesse, or younger accreted sediments with a similar composition. The composition of the lower crust over most of New Zealand is, however, unknown. A velocity anomaly of $-0.6 \mathrm{~km} \mathrm{~s}^{-1}$ corresponds to a density anomaly of $220 \mathrm{~kg} \mathrm{~m}^{-3}$ using the relation of Christensen and Mooney [1995], or $120 \mathrm{~kg} \mathrm{~m}^{-3}$ using the relation of Brocher [2005]. This is relative to average crust at this depth, and we note that the largest amplitude of the buoyancy anomaly is within the lower crust, where background velocities and inferred densities are higher.

[48] The absolute velocity within the velocity anomaly provides insight into the underplated rock type. Torlesse Supergroup rocks are the fully compacted end-member of a fore-arc sedimentary rock within eastern New Zealand and are shown to have a velocity of $6.3+/-0.4 \mathrm{~km} \mathrm{~s}^{-1}$ at $0.6 \mathrm{GPa}$, which is equivalent to $\sim 22 \mathrm{~km}$ depth [Christensen and Okaya, 2007]. The velocity determined at 23 $\mathrm{km}$ depth within the underplated anomaly is 5.9$6.1 \mathrm{~km} \mathrm{~s}^{-1}$. If the difference between this velocity and that of typical Torlesse Supergroup rocks is related to water-filled fractures, then a porosity of $3 \%-6 \%$ is implied by velocity-density relations [Christensen and Mooney, 1995; Brocher, 2005]. The difference in velocity is, however, barely significantly different from a typical volume of Torlesse rock averaged over seismic wavelengths. At depths of $30 \mathrm{~km}$ the velocity within the anomaly is exactly what would be expected for a Torlesse Supergroup rock or equivalent Cenozoic greywacke that has been entirely dewatered through burial.

[49] At depths of 5-20 km, the range of our model velocities beneath East Cape Ridge is $3.5-5.0 \mathrm{~km} \mathrm{~s}^{-1}$. A mean velocity of $4.2 \mathrm{~km} \mathrm{~s}^{-1}$ for a mean travel depth of $\sim 10 \mathrm{~km}$ and travel distance of $64 \mathrm{~km}$ is most robustly determined from arrivals from the 


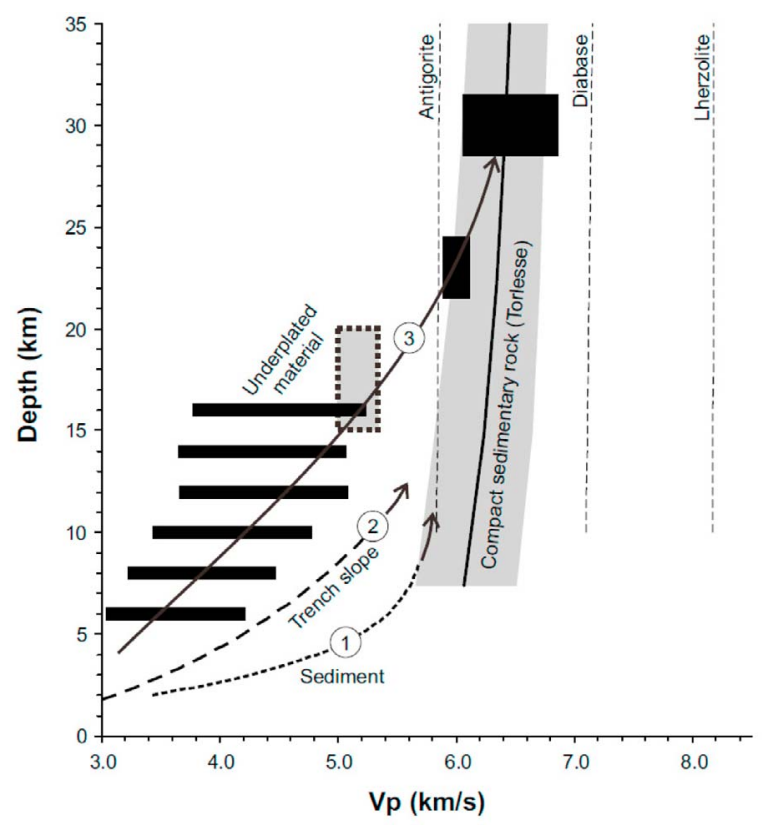

Figure 13. Relationship between $\mathrm{Vp}$ and depth for sedimentary basins (indicated by 1), the toe of the Hikurangi trench slope adjacent to central North Island [Barker et al., 2009] (indicated by 2), and the low-velocity prism beneath East Cape Ridge that we infer to be underplated material (indicated by 3 ). For comparison we also show laboratory measurements of compact sedimentary basement rocks of the Torlesse Supergroup [Christensen and Okaya, 2007] and reference velocities for serpentinite (antigorite), ocean crust (diabase), and mantle (lherzolite) rock types [Hacker and Abers, 2004]. We suggest that the very slow velocities we observe beneath East Cape Ridge may be interpreted as a suppressed compaction trend for sediment and fault rock that has been rapidly transported and then underplated at midcrustal depths.

eastern end of line RAU07-07. These arrivals are from refracted and reflected (from the subduction interface) raypaths that are almost entirely within the low-velocity body (see auxiliary material). The mean velocity of $4.2 \mathrm{~km} \mathrm{~s}^{-1}$ is much lower than can be explained by any common crustal rock found at an equivalent average depth of $\sim 10 \mathrm{~km}$ in any stable tectonic environment (Figure 13). Sedimentary rocks typically have velocities $>5.0 \mathrm{~km} \mathrm{~s}^{-1}$ at $>5 \mathrm{~km}$ depth, and are usually very close to a fully compacted rock velocity of $\sim 6.0 \mathrm{~km} \mathrm{~s}^{-1}$ by $10 \mathrm{~km}$ depth [Gardner et al., 1974; Brocher, 2005]. The absolute velocity we model $(\leq 5.0 \mathrm{~km} \mathrm{~s})$ is considerably lower than can be explained by a $100 \%$ hydrated serpentinite (Figure 13).

[50] Velocity depth relations in the upper $10 \mathrm{~km}$ of the trench slope farther south on the Hikurangi margin show a trend that is closer, but still faster at an equivalent depth [Barker et al., 2009]. Similar low velocities have been recorded at other subduction margins [e.g., Collot et al., 2008; Agudelo et al., 2009; Park et al., 2010; Kopp et al., 2000], but the velocities we determine at 5-20 km depth are among the slowest recorded at any margin. We suggest that high strain rates at subduction margins and elevated fluid pressure gradients caused by slab dehydration and dewatering of a subduction channel may keep fractures and pore space open in the hanging wall, resulting in anomalously slow velocities. The relatively low temperatures inferred for the northern Hikurangi margin [McCaffrey et al., 2008] may also play a role in helping to preserve rock strength and inhibit chemical reactions and hence keep fractures open.

[51] The porosity of the fractured underplated rock may be estimated using a similar logic to that employed for sedimentary rocks [Nafe and Drake, 1957; Erickson and Jarrard, 1998; Mavko et al., 1998]. We consider the underplated rock to be a mixture of Torlesse rock fragments and water. Hence, a velocity of $4.2 \mathrm{~km} \mathrm{~s}^{-1}$ is equivalent to a porosity of $12 \%-18 \%$, depending upon the precise relationship used [Nafe and Drake, 1957; Gardner et al., 1974; Erickson and Jarrard, 1998; Mavko et al., 1998; Brocher, 2005] and assuming a dewatering trend alone.

\subsection{Global Implications for Subduction Fluxes}

[52] Understanding the nature and interplay of constructive and destructive processes at subduction margins is important to address questions concerning the long-term growth of continents and the chemical differentiation of Earth over geological time [Rudnick and Fountain, 1995]. Through the compilation of seismic profiles at over 30 arcs of known/estimated Phanerozoic activity, the global flux of continental material to the mantle at subduction margins has been estimated [von Huene and Scholl, 1991; Clift and Vannucchi, 2004]. These estimates have progressively increased as more data have become available and recent estimates of global crustal loss are $74 \mathrm{~km}^{3} \mathrm{Ma}^{-1} \mathrm{~km}^{-1}$ (Figures 10a and 10b) [Clift et al., 2009]. The estimates are primarily based upon observed rates of fore-arc subsidence that are in turn inferred to be due to the tectonic erosion of crustal material into the mantle by the subducted plate.

[53] Using $\mathrm{Sm}-\mathrm{Nd}$ isotopic data from clastic and chemical sediments in conjunction with the present-day age distribution of continental crustal 
rocks, Jacobsen [1988] suggests that the volume of continental crust has been steadily growing throughout the Phanerozoic. This growth is hypothesized to offset a deepening of ocean basins in response to waning heat flow from the mantle, resulting in a generally constant degree of continental freeboard above mean sea level during the Phanerozoic [Schubert and Reymer, 1985]. To preserve the present degree of continental freeboard given the revised rate of global crustal loss presented within Clift et al. [2009], a global average rate of arc productivity of $75 \mathrm{~km}^{3} \mathrm{Ma}^{-1} \mathrm{~km}^{-1}$ is required. The assumption of constant freeboard, and the amplitude of long-term variations in mean sea level, requires a correlation between mean sea level and the volume of continental crust. A 175 m reduction in mean sea level since $65 \mathrm{Ma}$, if explained by operation of a net crustal deficit within the global subduction system, may suggest average arc production rates as low as $50 \mathrm{~km}^{3} \mathrm{Myr}^{-1} \mathrm{~km}^{-1}$ throughout the Cenozoic [Clift et al., 2009]. Despite these deductions, this value remains larger than previous estimates of arc productivity (20$40 \mathrm{~km}^{3} \mathrm{Ma}^{-1} \mathrm{~km}^{-1}$ [Reymer and Schubert, 1984]) and for reasons discussed below, may be systematically overstated.

[54] When calculating estimates of crustal loss, direct measurement of accretionary wedges is coupled with estimated average rates of sediment supply to calculate the proportions of sediment delivered to the trenches that are accreted and subducted. Even at accretionary margins (Figure 10a), the proportion of sediment subducted is estimated at $\sim 80 \%$ [von Huene and Scholl, 1991; Clift and Vannucchi, 2004]. The contribution of subduction erosion to rates of crustal loss are estimated from trench slope subsidence histories, which assuming vertical rock trajectories within the fore-arc wedge, are directly converted to rates of tectonic erosion (Figure 10b). We suggest that the use of local evidence of trench slope subsidence to infer widespread states of basal tectonic erosion may result in the systematic calculation of erosion rates that are too high. Moreover, the proportions of subducted and tectonically eroded sediment that is fluxed into the mantle may also be overstated as the retention of this material via lower crustal underplating is generally not accounted for.

[55] At the northern Hikurangi margin, the rate of underplating that we estimate $\left(20+/-7 \mathrm{~km}^{3} \mathrm{Ma}^{-1}\right.$ $\mathrm{km}^{-1}$ ) appears to be sufficient to counteract subduction erosion and facilitate a net crustal growth of the fore arc. Lower crustal underplating rates have also been estimated at the Andean margin in northern Chile and Peru, where subsidence and tectonic erosion offshore was also synchronous with rock uplift onshore [Clift and Hartley, 2007]. Using uplift rates preserved in Pleistocene marine terraces and isostatic calculations to estimate the volume of underplated material, Clift and Hartley [2007] calculate a rate of lower crustal underplating of $19-22 \mathrm{~km}^{3} \mathrm{Ma}^{-1} \mathrm{~km}^{-1}$.

[56] We suggest that lower crustal underplating is more widespread than previously recognized and requires a reduction in the estimate of the flux of continental material into the mantle. Such a reduction will correspondingly reduce the rate of arc productivity required to maintain continental freeboard, and brings the estimate closer to published estimates of arc productivity [Reymer and Schubert, 1984]. In addition, the theoretical flux of continental material through the magmatic arc will also be reduced, in better agreement with the geochemical signature of arc volcanic output [Woodhead and Fraser, 1985; Ewart and Hawkesworth, 1987; Vroon et al., 1993]. We suggest that the rates of crustal underplating calculated in this study may be scaled to other margins and are sufficient to resolve the discrepancy between the inputs and outputs at global subduction margins within analytical uncertainty.

\section{Conclusions}

[57] We have integrated new onshore-offshore wide-angle seismic refraction data with published ocean bottom seismic refraction [Scherwath et al., 2010] and multichannel seismic reflection profiles [Sutherland et al., 2009] to model the 3-D crustal structure beneath a $32,000 \mathrm{~km}^{2}$ area of the northern Hikurangi subduction margin.

[58] Southwest, along strike, our velocity model resolves within the fore arc a $>10 \mathrm{~km}$ increase in Moho depth (Figure 8) and a $>20 \mathrm{~km}$ increase in basement thickness between Raukumara Basin and the Raukumara Peninsula (Figure 7b). The increase in Moho depth trends west-east and is inversely correlated with topography.

[59] Beneath the topographic crest of East Cape Ridge and Raukumara Peninsula, low velocities $\left(3.5-5.0 \mathrm{~km} \mathrm{~s}^{-1}\right)$ are resolved within a triangular prism with cross-sectional area $>200 \mathrm{~km}^{2}$ positioned above the subduction interface. We interpret the low-velocity $\left(3.5-5.0 \mathrm{~km} \mathrm{~s}^{-1}\right)$ prism as underplated sedimentary and crustal material.

[60] Assuming that the prism of low-velocity (3.5$5.0 \mathrm{~km} \mathrm{~s}^{-1}$ ) material has accumulated since the 


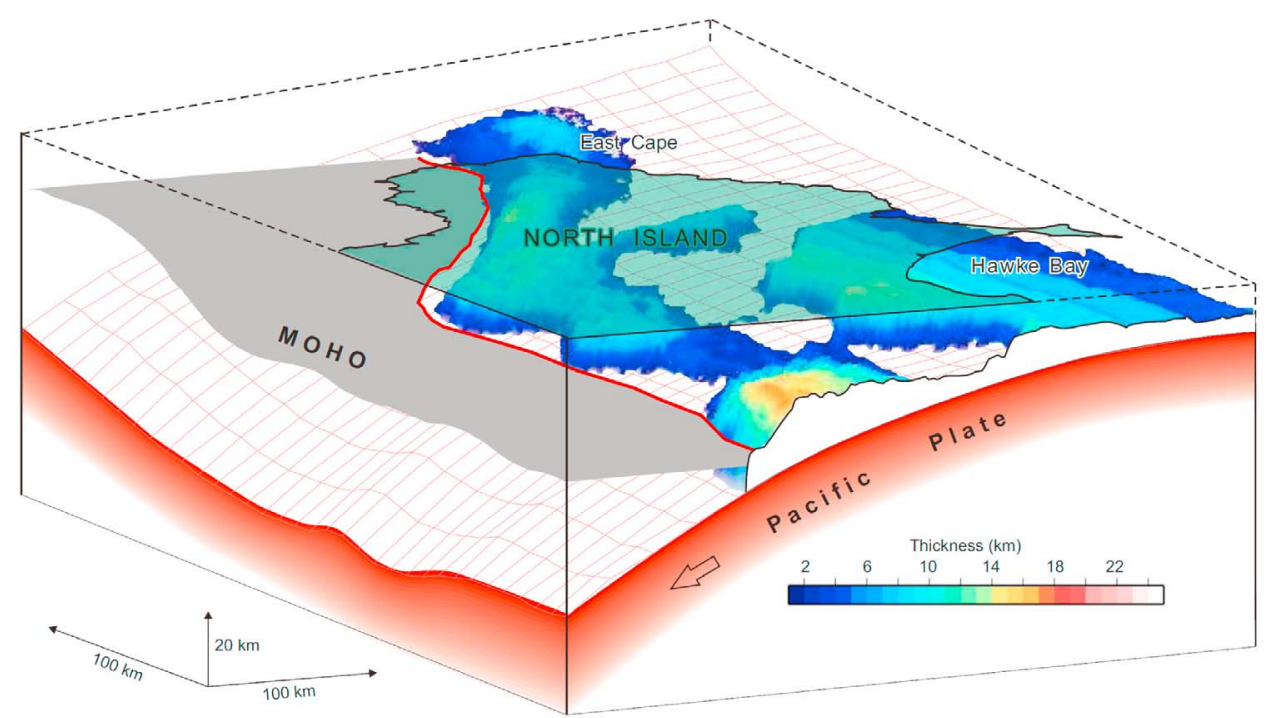

Figure 14. Perspective plot displaying the geometry of the low-velocity volume resolved using a threshold value of $-0.6 \mathrm{~km} \mathrm{~s}^{-1}$. We also show the fore-arc Moho (dark gray surface) and subducting slab (red mesh). Solid red line marks the point of intersection between the subducting slab and fore-arc Moho. Green transparency marks the eastern North Island land area.

onset of subduction at $22 \mathrm{Ma}$, we calculate the rate of underplating at the northern Hikurangi margin to be in the range $10-25 \mathrm{~km}^{3} \mathrm{Ma}^{-1} \mathrm{~km}^{-1}$. The upper bound assumes that the trench slope is composed of deformed accreted material, though the accretion rate may be even higher if some of the accreted material has since been eroded either by surface or tectonic processes. Based upon the lack of fossil arc volcanoes within Raukumara Basin and the arcward growth of East Cape Ridge, it was previously suggested that net accretion is occurring at the margin [Sutherland et al., 2009], and hence we suggest that this underplating rate is greater than the tectonic erosion rate.

[61] Southward along East Cape Ridge, our model shows that both the prism and topographic crest migrate arcward (Figure $7 \mathrm{~b}$ ). The spatial correlation we observe between the arcward/inboard edge of the low-velocity prism and the intersection between the subduction interface and fore-arc Moho suggests that the location of lower crustal underplating is modulated by Moho depth. This is consistent with the previously proposed cyclical fore-arc crustal dynamic in which the density of subducted and tectonically eroded strata is sufficient for it to escape from the subduction channel near the base of the crust, driving surface uplift, oversteeping, and gravitational collapse of the trench slope [Sutherland et al., 2009; Scherwath et al., 2010].

[62] By integrating our new 3-D grid with published grids of the velocity structure farther south, we show that a $350 \mathrm{~km}$ length of the northern Hikurangi margin has an average underplating rate of $20+/-7 \mathrm{~km}^{3} \mathrm{Ma}^{-1} \mathrm{~km}^{-1}$, and we infer net growth of the margin (Figure 14). The velocity anomaly is greatest in the lower crust, which is in keeping with our inference that the density layering of the crust and Moho is a primary control on the underplating mechanism. Analysis of absolute velocities within the underplated volume and consideration of the uniform sedimentary compositions available for underplating suggests that the underplated material dewaters as it is tectonically transported and accreted, and behaves in a similar fashion to sedimentary rocks as they are buried. However, underplated material follows a much more suppressed compaction curve than sedimentary basins and may maintain porosities as high as $12 \%-18 \%$ at $10 \mathrm{~km}$ depth.

[63] We suggest that the rate of lower crustal underplating at convergent margins is higher than accounted for in most previous global estimates of crustal creation and destruction [e.g., von Huene and Scholl, 1991; Clift and Vannucchi, 2004]. At the Hikurangi margin we suggest that the rate of crustal underplating is greater than fore-arc tectonic erosion, and if the rate of lower crustal underplating calculated in this study is similar to other margins, then this observation could resolve the discrepancy between published estimates of continental creation [Reymer and Schubert, 1984] and destruction [von Huene and Scholl, 1991; Clift and Vannucchi, 2004]. 


\section{Acknowledgments}

[64] We thank Rosanne Simes, Yanik Behr, and Nicholas Henrys for help with deployment and retrieval of seismometers; Stephen Bannister and Mike Milner for assistance with processing and analysis of data; and Geoffroy Lamarche and Simon Bardsley of NIWA for the provision of bathymetric and seismic data. Nick Rawlinson (ANU) and Nicolas Brikke are thanked for software support and assistance concerning the application of FMTOMO. Hannu Seebeck is thanked for providing grids of subducting slab geometry. This work was funded by Victoria University and the NZ Foundation for Research Science and Technology.

\section{References}

Agudelo, W., A. Ribodetti, J.-Y. Collot, and S. Operto (2009), Joint inversion of multichannel seismic reflection and wideangle seismic data: Improved imaging and refined velocity model of the crustal structure of the north Ecuador-south Colombia convergent margin, J. Geophys. Res., 114, B02306, doi:10.1029/2008JB005690.

Ballance, P. F., A. G. Ablaev, I. K. Pushchin, S. P. Pletnev, M. G. Birylina, T. Itaya, H. A. Follas, and G. W. Gibson (1999), Morphology and history of the Kermadec trencharc-backarc basin remnant arc system at 30 to $32^{\circ} \mathrm{S}$ : Geophysical profile, microfossil and K-Ar data, Mar. Geol., 159(1-4), 35-62.

Bannister, S., C. J. Bryan, and H. M. Bibby (2004), Shear wave velocity variation across the Taupo Volcanic Zone, New Zealand, from receiver function inversion, Geophys. J. Int., 159(1), 291-310, doi:10.1111/j.1365-246X.2004. 02384.x.

Barker, D. H. N., R. Sutherland, S. Henrys, and S. Bannister (2009), Geometry of the Hikurangi subduction thrust and upper plate, North Island, New Zealand, Geochem. Geophys. Geosyst., 10, Q02007, doi:10.1029/2008GC002153.

Beavan, J., P. Tregoning, M. Bevis, T. Kato, and C. Meertens (2002), Motion and rigidity of the Pacific Plate and implications for plate boundary deformation, J. Geophys. Res., 107(B10), 2261, doi:10.1029/2001JB000282.

Brocher, T. M. (2005), Empirical relations between elastic wavespeeds and density in the Earth's crust, Bull. Seismol. Soc. Am., 95(6), 2081-2092, doi:10.1785/0120050077.

Christensen, N. I., and W. D. Mooney (1995), Seismic velocity structure and composition of the continental crust: A global view, J. Geophys. Res., 100, 9761-9788, doi:10.1029/ 95JB00259.

Christensen, N., and D. Okaya (2007), Compressional and shear-wave velocities in South Island New Zealand rocks and their application to the interpretation of seismological models models of the New Zealand crust, in A Continental Plate Boundary: Tectonics at South Island, New Zealand, Geophys. Monogr. Ser., vol. 175, edited by D. Okaya et al., pp. 125-155, AGU, Washington, D. C.

Clift, P., and A. Hartley (2007), Slow rates of subduction erosion and coastal underplating along the Andean margin of Chile and Peru, Geology, 35(6), 503-506, doi:10.1130/ G23584A.1.

Clift, P., and P. Vannucchi (2004), Controls on tectonic accretion versus erosion in subduction zones: Implications for the origin and recycling of the continental crust, Rev. Geophys., 42, RG2001, doi:10.1029/2003RG000127.

Clift, P., et al. (2009), Crustal redistribution, crust-mantle recycling and Phanerozoic evolution of the continental crust, Earth Sci. Rev., 97, 80-104, doi:10.1016/j.earscirev.2009. 10.003 .

Collot, J. Y., and B. Davy (1998), Forearc structures and tectonic regimes at the oblique subduction zone between the Hikurangi Plateau and the southern Kermadec margin, J. Geophys. Res., 103, 623-650, doi:10.1029/97JB02474.

Collot, J.-Y., K. Lewis, G. Lamarche, and S. Lallemand (2001), The giant Ruatoria debris avalanche on the northern Hikurangi margin, New Zealand: Result of oblique seamount subduction, J. Geophys. Res., 106, 19,271-19,297, doi:10.1029/2001JB900004.

Collot, J.-Y., W. Agudelo, A. Ribodetti, and B. Marcaillou (2008), Origin of a crustal splay fault and its relation to the seismogenic zone and underplating at the erosional north Ecuador-south Colombia oceanic margin, J. Geophys. Res., 113, B12102, doi:10.1029/2008JB005691.

Davey, F. J., S. Henrys, and E. Lodolo (1997), A seismic crustal section across the East Cape convergent margin, New Zealand, Tectonophysics, 269(3-4), 199-215, doi:10.1016/S0040-1951(96)00165-5.

Davy, B., and J. Collot (2000), The Rapuhia Scarp (northern Hikurangi Plateau) - Its nature and subduction effects on the Kermadec Trench, Tectonophysics, 328(3-4), 269-295, doi:10.1016/S0040-1951(00)00211-0.

Davy, B., and R. Wood (1994), Gravity and magnetic modelling of the Hikurangi Plateau, Mar. Geol., 118(1-2), 139-151, doi:10.1016/0025-3227(94)90117-1.

Davy, B., K. Hoernle, and R. Werner (2008), Hikurangi Plateau: Crustal structure, rifted formation, and Gondwana subduction history, Geochem. Geophys. Geosyst., 9, Q07004, doi:10.1029/2007GC001855.

de Kool, M., N. Rawlinson, and M. Sambridge (2006), A practical grid-based method for tracking multiple refraction and reflection phases in three-dimensional heterogeneous media, Geophys. J. Int., 167(1), 253-270, doi:10.1111/j.1365-246X. 2006.03078.x.

DeMets, C., R. G. Gordon, D. F. Argus, and S. Stein (1994), Effect of recent revisions to the geomagnetic reversal time scale on estimates of current plate motions, Geophys. Res. Lett., 21(20), 2191-2194, doi:10.1029/94GL02118.

Dickinson, W. R., and D. R. Seely (1979), Structure and stratigraphy of forearc regions, AAPG Bull., 63(1), 2-31.

Dowling, J. J. (1968), The east coast onshore-offshore experiment, II. Seismic refraction measurements on the Continental Shelf between Cape Hatteras and Cape Fear, Bull. Seismol. Soc. Am., 58(3), 821-834.

Eberhart-Phillips, D., and M. Chadwick (2002), Threedimensional attenuation model of the shallow Hikurangi subduction zone in the Raukumara Peninsula, New Zealand, J. Geophys. Res., 107(B2), 2033, doi:10.1029/2000JB000046.

Eberhart-Phillips, D., and M. Reyners (1999), Plate interface properties in the Northeast Hikurangi Subduction Zone, New Zealand, from converted seismic waves, Geophys. Res. Lett., 26(16), 2565-2568, doi:10.1029/1999GL900567.

Erickson, S. N., and R. D. Jarrard (1998), Velocity-porosity relationships for water-saturated siliciclastic sediments, J. Geophys. Res., 103(B12), 30,385-30,406, doi:10.1029/ 98JB02128.

Ewart, A., and C. J. Hawkesworth (1987), The PleistoceneRecent Tonga-Kermadec arc lavas: Interpretation of new 
isotopic and rare earth data in terms of a depleted mantle source model, J. Petrol., 28(3), 495-530.

Fugro Seismic Imaging (2007), Raukumara Basin 2D Seismic Survey-RAU07, New Zealand, open file petroleum report, pp. 1-37, Crown Miner., Min. of Econ. Dev., Wellington.

Gardner, G. H., et al. (1974), Formation of velocity and density-The diagnostic basics for stratigraphic traps, Geophysics, 39, 770-780, doi:10.1190/1.1440465.

Gillies, P. (1984), A marine geophysical study of the junction of the Kermadec and Hikurangi subduction systems, Ph.D. thesis, Univ. of Auckland, Auckland, New Zealand.

Gillies, P. N., and F. J. Davey (1986), Seismic reflection and refraction studies of the Raukumara forearc basin, New Zealand, N. Z. J. Geol. Geophys., 29(4), 391-403.

Hacker, B. R., and G. A. Abers (2004), Subduction Factory 3: An Excel worksheet and macro for calculating the densities, seismic wave speeds, and $\mathrm{H}_{2} \mathrm{O}$ contents of minerals and rocks at pressure and temperature, Geochem. Geophys. Geosyst., 5, Q01005, doi:10.1029/2003GC000614.

Hawkesworth, C. J., and A. I. Kemp (2006), Evolution of the continental crust, Nature, 443, 811-817, doi:10.1038/ nature 05191.

Henrys, S., et al. (2006), Kinking of the subducting slab by escalator normal faulting beneath the North Island of New Zealand, Geology, 34(9), 777-780, doi:10.1130/G22594.1.

Horspool, N. A., M. K. Savage, and S. Bannister (2006), Implications for intraplate volcanism and back-arc deformation in northwestern New Zealand, from joint inversion of receiver functions and surface waves, Geophys. J. Int., 166(3), 1466-1483, doi:10.1111/j.1365-246X.2006.03016.x.

Jacobsen, S. B. (1988), Isotopic constraints on crustal growth and recycling, Earth Planet. Sci. Lett., 90, 315-329, doi:10.1016/0012-821X(88)90133-1.

Katz, H. R. (1974), Margins of the southwest Pacific, in The Geology of Continental Margins, pp. 549-565, Springer, New York.

Kopp, C., et al. (2000), Structure of the Makran subduction zone from wide-angle and reflection seismic data, Tectonophysics, 329(1-4), 171-191, doi:10.1016/S0040-1951(00) 00195-5.

Lafond, C. F., and A. Levander (1995), Migration of wideaperture onshore-offshore seismic data, central California: Seismic images of late stage subduction, J. Geophys. Res., 100(B11), 22,231-22,243, doi:10.1029/95JB01968.

Lallemand, S. (1995), High rates of arc consumption by subduction processes: Some consequences, Geology, 23(6), 551-554, doi:10.1130/0091-7613(1995)023<0551: HROACB $>2.3 . \mathrm{CO} ; 2$.

Lamarche, G., P. M. Barnes, and J. M. Bull (2006), Faulting and extension rate over the last 20,000 years in the offshore Whakatane Graben, New Zealand continental shelf, Tectonics, 25, TC4005, doi:10.1029/2005TC001886.

Lamb, S. H. (1988), Tectonic rotations about vertical axes during the last $4 \mathrm{Ma}$ in part of the New Zealand plate-boundary zone, J. Struct. Geol., 10(8), 875-893, doi:10.1016/01918141(88)90101-0.

Lewis, K. B., S. E. Lallemand, and L. Carter (2004), Collapse in a Quaternary shelf basin off East Cape, New Zealand: Evidence for passage of a subducted seamount inboard of the Ruatoria giant avalanche, N. Z. J. Geol. Geophys., 47, 415-429.

Litchfield, N., and K. Berryman (2006), Relations between postglacial fluvial incision rates and uplift rates in the North Island, New Zealand, J. Geophys. Res., 111, F02007, doi:10.1029/2005JF000374.
Litchfield, N., et al. (2007), Insights into subduction-related uplift along the Hikurangi Margin, New Zealand, using numerical modeling, J. Geophys. Res., 112, F02021, doi:10.1029/2006JF000535.

Maslen, G. (2005), Fast track seismic processing of selected data from the $05 \mathrm{CM}$ survey offshore east coast, New Zealand, Open File Pet. Rep., 3182, Crown Miner., Minist. of Econ. Dev., Wellington.

Mavko, G., et al. (1998), The Rock Physics Handbook, 329 pp., Cambridge Univ. Press, Cambridge, U. K.

McCaffrey, R., L. M. Wallace, and J. Beavan (2008), Slow slip and frictional transition at low temperature at the Hikurangi subduction zone, Nat. Geosci., 1(5), 316-320, doi:10.1038/ ngeo178.

Multiwave (2005), 05CM 2D seismic survey, offshore east coast-North Island, New Zealand, Open File Pet. Rep., 3136, pp. 1-280, Crown Miner., Minist. of Econ. Dev., Wellington.

Nafe, J. E., and C. L. Drake (1957), Variation with depth in shallow and deep water marine sediments of porosity, density and the velocities of compressional shear waves, Geophysics, 22(3), 523-552, doi:10.1190/1.1438386.

Nicol, A., C. Mazengarb, F. Chanier, G. Rait, C. Uruski, and L. Wallace (2007), Tectonic evolution of the active Hikurangi subduction margin, New Zealand, since the Oligocene, Tectonics, 26, TC4002, doi:10.1029/2006TC002090.

Park, J. O., et al. (2010), A low-velocity zone with weak reflectivity along the Nankai subduction zone, Geology, 38(3), 283-286, doi:10.1130/G30205.1.

Rawlinson, N., and M. Sambridge (2004a), Multiple reflection and transmission phases in complex layered media using a multistage fast marching method, Geophysics, 69(5), 1338-1350, doi:10.1190/1.1801950.

Rawlinson, N., and M. Sambridge (2004b), Wave front evolution in strongly heterogeneous layered media using the fast marching method, Geophys. J. Int., 156(3), 631-647, doi:10.1111/j.1365-246X.2004.02153.x.

Rawlinson, N., and M. Urvoy (2006), Simultaneous inversion of active and passive source datasets for 3-D seismic structure with application to Tasmania, Geophys. Res. Lett., 33, L24313, doi:10.1029/2006GL028105.

Reymer, A., and G. Schubert (1984), Phanerozoic addition rates to the continental crust and crustal growth, Tectonics, 3(1), 63-77, doi:10.1029/TC003i001p00063.

Reyners, M., and P. McGinty (1999), Shallow subduction tectonics in the Raukumara Peninsula, New Zealand, as illuminated by earthquake focal mechanisms, J. Geophys. Res., 104(B2), 3025-3034, doi:10.1029/1998JB900081.

Reyners, M., D. Eberhart-Phillips, and G. Stuart (1999), A three-dimensional image of shallow subduction: Crustal structure of the Raukumara Peninsula, New Zealand, Geophys. J. Int., 137(3), 873-890, doi:10.1046/j.1365-246x. 1999.00842.x.

Reyners, M., et al. (2006), Imaging subduction from the trench to $300 \mathrm{~km}$ depth beneath the central North Island, New Zealand, with Vp and Vp/Vs, Geophys. J. Int., 165(2), 565-583, doi:10.1111/j.1365-246X.2006.02897.x.

Rudnick, R. L., and D. M. Fountain (1995), Nature and composition of the continental crust: A lower-crustal perspective, Rev. Geophys., 33(3), 267-309, doi:10.1029/95RG01302.

Scherwath, M., T. Stern, F. Davey, D. Okaya, W. S. Holbrook, R. Davies, and S. Kleffmann (2003), Lithospheric structure across oblique continental collision in New Zealand from wide-angle $P$ wave modeling, J. Geophys. Res., 108(B12), 2566, doi:10.1029/2002JB002286. 
Scherwath, M., et al. (2010), Fore-arc deformation and underplating at the northern Hikurangi margin, New Zealand, J. Geophys. Res., 115, B06408, doi:10.1029/2009JB006645.

Schubert, G., and A. P. S. Reymer (1985), Continental volume and freeboard through geological time, Nature, 316, 336-339.

Sethian, J. A. (1996), A fast marching level set method for monotonically advancing fronts, Proc. Natl. Acad. Sci. U. S. A., 93(4), 1591, doi:10.1073/pnas.93.4.1591.

Sethian, J. A., and A. M. Popovici (1999), Three dimensional traveltimes computation using the Fast Marching Method, Geophysics, 64(2), 516-523, doi:10.1190/1.1444558.

Spence, G. D., R. M. Clowes, and R. M. Ellis (1985), Seismic structure across the active subduction zone of western Canada, J. Geophys. Res., 90, 6754-6772, doi:10.1029/ JB090iB08p06754.

Stagpoole, V., et al. (2008), Petroleum prospectivity of the Raukumara Basin, New Zealand, Consult. Rep., 2008/111, GNS Sci., Lower Hutt, New Zealand.

Stern, R. J. (2002), Subduction zones, Rev. Geophys., 40(4), 1012, doi:10.1029/2001RG000108.

Stern, T. A., and F. J. Davey (1985), Crustal structure studies within the central North Island: The central volcanic region, Rep., 207, 47 pp., Geophys. Div., Dep. of Sci. and Ind. Res., Wellington.

Stern, T., et al. (2001), Low seismic-wave speeds and enhanced fluid pressure beneath the Southern Alps of New Zealand, Geology, 29(8), 679-682, doi:10.1130/0091-7613 (2001)029<0679:LSWSAE $>2.0 . C O ; 2$.

Sutherland, R., et al. (2009), Reactivation of tectonics, crustal underplating, and uplift after $60 \mathrm{Myr}$ of passive subsidence, Raukumara Basin, Hikurangi-Kermadec fore arc, New Zealand: Implications for global growth and recycling of continents, Tectonics, 28, TC5017, doi:10.1029/2008TC002356.

Tréhu, A. M., G. Lin, E. Maxwell, and C. Goldfinger (1995), A seismic reflection profile across the Cascadia subduction zone offshore central Oregon: New constraints on methane distribution and crustal structure, J. Geophys. Res., 100(B8), 15,101-15,116, doi:10.1029/95JB00240.

von Huene, R., and D. W. Scholl (1991), Observations at convergent margins concerning sediment subduction, subduction erosion, and the growth of continental crust, Rev. Geophys., 29(3), 279-316, doi:10.1029/91RG00969.

Vroon, P. Z., M. J. van Bergen, W. M. White, and J. C. Varekamp (1993), Sr-Nd-Pb isotope systematics of the Banda Arc, Indonesia: Combined subduction and assimilation of continental material, J. Geophys. Res., 98(B12), 22,349-22,366.

Walcott, R. I. (1984), The kinematics of the plate boundary zone through New Zealand: A comparison of short-and long-term deformations, Geophys. J. Int., 79, 613-633, doi:10.1111/j.1365-246X.1984.tb02244.x.

Walcott, R. I. (1987), Geodetic strain and the deformational history of the North Island of New Zealand during the late Cainozoic, Philos. Trans. R. Soc. London, Ser. A, 321, 163-181, doi:10.1098/rsta.1987.0009.

Wallace, L. M., J. Beavan, R. McCaffrey, and D. Darby (2004), Subduction zone coupling and tectonic block rotations in the North Island, New Zealand, J. Geophys. Res., 109, B12406, doi:10.1029/2004JB003241.

Wilson, K., et al. (2007), Distribution, age, and uplift patterns of Pleistocene marine terraces of the northern Raukumara Peninsula, North Island, New Zealand, N. Z. J. Geol. Geophys., 50, 181-191.

Woodhead, J. D., and D. G. Fraser (1985), Pb, Sr and ${ }^{10} \mathrm{Be}$ isotopic studies of volcanic rocks from the Northern Mariana Islands. Implications for magma genesis and crustal recycling in the western Pacific, Geochim. Cosmochim. Acta, 49(9), 1925-1930, doi:10.1016/0016-7037(85)90087-0. 